bioRxiv preprint doi: https://doi.org/10.1101/2021.03.23.436572; this version posted March 23, 2021. The copyright holder for this preprint (which was not certified by peer review) is the author/funder, who has granted bioRxiv a license to display the preprint in perpetuity. It is made available under aCC-BY 4.0 International license.

Acquisition of MEKi resistance during DNA replication in drug

Channathodiyil et al.

\title{
DNA replication during acute MEK inhibition drives acquisition of resistance through amplification of the BRAF oncogene
}

Prasanna Channathodiyil ${ }^{1,2}$, Anne Segonds-Pichon ${ }^{3}$, Paul D. Smith ${ }^{4}$, Simon J. Cook ${ }^{5}$ and Jonathan Houseley ${ }^{1,6, *}$

${ }^{1}$ Epigenetics Programme, Babraham Institute, Cambridge, UK

2 ORCID: 0000-0002-9381-6089

${ }^{3}$ Babraham Bioinformatics, Babraham Institute, Cambridge, UK. ORCID: 0000-0002-83694882

${ }^{4}$ Oncology R\&D, AstraZeneca CRUK Cambridge Institute, Cambridge, UK

${ }^{5}$ Signalling programme, Babraham Institute, Cambridge, UK. ORCID: 0000-0001-9087-1616

${ }^{6}$ ORCID: 0000-0001-8509-1500

*Corresponding author: jon.houseley@babraham.ac.uk

\begin{abstract}
Mutations and gene amplifications that confer drug resistance emerge frequently during chemotherapy, but their mechanism and timing is poorly understood. Here, we investigate $B R A F^{V 600 E}$ amplification events that underlie resistance to the MEK inhibitor selumetinib (AZD6244/ARRY-142886) in COLO205 cells. We find that de novo focal BRAF amplification is the primary path to resistance irrespective of pre-existing amplifications. Although selumetinib causes long-term G1 arrest, we observe that cells stochastically re-enter the cell cycle during treatment without reactivation of ERK1/2 or induction of a normal proliferative gene expression programme. Genes encoding DNA replication and repair factors are downregulated during $\mathrm{G} 1$ arrest, but many are transiently induced when cells escape arrest and enter $S$ and $G 2$. Nonetheless, mRNAs encoding key DNA replication factors including the MCM replicative helicase complex, PCNA and TIPIN remain at very low abundance, which likely explains previous reports of replication stress and mutagenesis under long-term RAFMEK-ERK1/2 pathway inhibition. To test the hypothesis that DNA replication in drug promotes de novo BRAF amplification, we exploited the combination of palbociclib and selumetinib to reinforce the $\mathrm{G} 1$ arrest. Using a palbociclib dose that suppresses cell cycle entry during selumetinib treatment but not during normal proliferation, we show that combined treatment robustly delays the emergence of drug resistant colonies. Our results demonstrate that acquisition of MEK inhibitor resistance can occur through de novo gene amplification events resulting from DNA replication in drug, and is suppressed by drug combinations that impede cell cycle entry.
\end{abstract}


bioRxiv preprint doi: https://doi.org/10.1101/2021.03.23.436572; this version posted March 23, 2021. The copyright holder for this preprint (which was not certified by peer review) is the author/funder, who has granted bioRxiv a license to display the preprint in perpetuity. It is made available under aCC-BY 4.0 International license.

Acquisition of MEKi resistance during DNA replication in drug

Channathodiyil et al.

\section{Introduction}

The development of targeted anti-cancer drugs has improved treatment efficacy and reduced side effects but drug resistance still limits long-term patient survival $(1,2)$. Mutations and gene amplifications affecting the drug target or proteins in downstream pathways allow reemergence of tumours that are refractory to treatment with the original and related chemotherapeutics $(3,4)$. For example, tumours resistant to the EGFR inhibitors gefitinib and erlotinib normally carry EGFR ${ }^{T 790 M}$ mutations that impair drug binding, or MET amplifications that bypass EGFR to activate PI3K-Akt signalling (5-7).

In addition to PI3K, EGFR activates the RAS-RAF-MEK-ERK1/2 pathway (hereafter, ERK1/2 pathway), a major regulator of cell survival and proliferation. Constitutive activation of this pathway resulting from mutational activation of BRAF or RAS proteins occurs in the majority of melanomas and colorectal cancers $(8,9)$. Consequently, the ERK $1 / 2$ pathway is a major target for drug development and inhibitors of RAF and MEK are approved for treatment of melanoma, whilst ERK1/2 inhibitors are undergoing clinical trials; however, patients often relapse with drug-resistant tumours $(10,11)$. Selumetinib (AZD6244/ARRY-142886) is a highly specific MEK inhibitor (MEKi) that suppresses constitutive activity of the ERK1/2 pathway, shows promise in pre-clinical studies (12-14) and has been approved for paediatric neurofibromatosis type 1 (NF1). However, resistance to MEKi arises frequently through amplification of BRAF or RAS (15-19) or through MEK mutation (20).

Cancer cells are genetically heterogeneous and rare pre-existing mutations that confer drug resistance may be selected for during treatment $(21,22)$. However, de novo mutations that occur during drug exposure can also cause resistance (23), in which case cells must survive initial drug application and then acquire mutations that restore proliferation. In culture, and recently in vivo, small numbers of drug tolerant persister (DTP) cells have been observed to survive extended treatment with targeted chemotherapeutics (24-27). DTPs exist in a nonproliferative or slow cycling state with gene expression patterns and metabolic states distinct from untreated and resistant populations (24-26, 28-31). However, proliferative colonies routinely emerge from DTPs in the presence of drug after long periods of apparent stasis, marking the DTP state as a precursor to resistance $(23,25-27)$. DTPs do not stem from a genetically defined subpopulation in the parental cell line and are not inherently drug resistant since removal from drug restores normal susceptibility $(24,26,27)$; instead DTPs represent an epigenetic state of the parental cell line that is dependent on histone demethylases and deacetylases for maintenance $(25,27,28,30)$.

Colonies of resistant cells derived from DTPs carry drug resistance mutations of unknown provenance. For example, erlotinib-resistant clones derived from a single clonal parental cell line exhibited diverse mutations including single nucleotide variants and gene amplifications in components of the ERK1/2 pathway (32). These clones formed from a clonal parental cell line with kinetics matching de novo rather than pre-existing erlotinib-resistance mutations $(23,32)$, suggesting that mutations arise de novo during treatment. Recently, EGFR inhibition amongst other treatments was shown to downregulate DNA replication and repair genes 
bioRxiv preprint doi: https://doi.org/10.1101/2021.03.23.436572; this version posted March 23, 2021. The copyright holder for this preprint (which was not certified by peer review) is the author/funder, who has granted bioRxiv a license to display the preprint in perpetuity. It is made available under aCC-BY 4.0 International license.

Acquisition of MEKi resistance during DNA replication in drug

Channathodiyil et al.

while inducing error prone DNA polymerase genes, which may represent an adaptive mutability response to chemotherapeutic challenge (33-35). However, slow cycling cells in unchallenged populations exhibit a similar gene expression signature (36), and upregulation of error prone DNA polymerases is not necessarily mutagenic (37). Therefore, changes in expression of genome maintenance factors may be a consequence of the transition to a slowgrowing DTP state and may not be innately mutagenic.

The cause of de novo mutations in DTPs, whether accidental or actively induced, is of great interest as mutagenic mechanisms that act during therapy could be inhibited to slow the acquisition of resistance. Here, we demonstrate that selumetinib resistance arises predominantly through de novo BRAF amplifications in colorectal cancer cells. We further show that DTPs occasionally enter $S$ phase during selumetinib treatment without inducing key cell cycle-regulated DNA replication genes, potentially providing a mutagenic environment for the emergence of de novo gene amplifications. Finally, we show that reducing the frequency with which DTPs replicate delays the emergence of selumetinib resistance.

\section{Results}

Selumetinib resistance in COLO205 cells arises primarily through de novo BRAF V600E amplification

Colorectal cancer cells carrying the $B R A F^{V 600 E}$ mutation can overcome MEK inhibition by amplification of $B R A F^{V 600 E}$, increasing levels of BRAF ${ }^{V 600 E}$ protein to activate more MEK and sustain ERK1/2 activity $(15,16)$. However, such $B R A F^{V 600 E}$-amplified cells become addicted to MEKi; withdrawal of MEKi drives excessive MEK-ERK1/2 activity due to amplified BRAF ${ }^{\mathrm{V} 600 \mathrm{E}}$, resulting in cell cycle arrest, senescence and apoptosis $(16,38)$. This in turn suggests that de novo BRAF amplifications may be the cause of MEKi resistance because BRAF V600E amplifications sufficient for resistance would not be tolerated in a drug-naïve cell. Nonetheless, pre-existing BRAF-amplified cells ( $4 \%)$ have been reported in drug naïve colorectal cancer cells (15). These conflicting observations, made in cell lines derived from the same tumour, led us to investigate the contributions of pre-existing and de novo BRAF V600E amplifications to the emergence of MEKi resistance.

To determine the frequency of $B R A F^{V 600 E}$ amplification among independently-derived resistant clones, 24 replicate cultures of COLO205 were treated with $1 \mu \mathrm{M}$ selumetinib ( 10 times the $\mathrm{IC}_{50}$ value for inhibition of proliferation of the parental cells (16)) for 8-10 weeks until proliferating drug-resistant clones were observed in 23/24 cultures (Fig. 1A). As a culture may contain multiple resistant clones, we purified each resistant culture by re-derivation from a single cell maintained in selumetinib. qPCR for BRAF copy number revealed a variable but at least 3-fold amplification of BRAF in 21 of 23 resistant cell lines (91\%), demonstrating that acquisition of selumetinib resistance through $B R A F$ amplification is reproducible and frequent in COLO205 cells (Fig. 1B) (38). Normalisation of BRAF qPCR to control loci on the same chromosome or a different chromosome gave equivalent results, showing that $B R A F$ is subject 
bioRxiv preprint doi: $\mathrm{https}$ ://doi.org/10.1101/2021.03.23.436572; this version posted March 23, 2021. The copyright holder for this preprint (which was not certified by peer review) is the author/funder, who has granted bioRxiv a license to display the preprint in perpetuity. It is made available under aCC-BY 4.0 International license.

Acquisition of MEKi resistance during DNA replication in drug

Channathodiyil et al.

to focal amplification rather than whole chromosome aneuploidy (compare Fig. S1A to Fig. 1B).

If $B R A F$-amplified cell lines derive from a pre-existing subpopulation, they will show identical amplification breakpoints in multiple independently derived cell lines. To test this, we acquired copy number profiles from parental COLO205 cells and 7 selumetinib-resistant cell lines using CytoSNP-850K Beadchip arrays. All seven resistant cell lines carried focal amplifications in the region encompassing BRAF (7q34) (Fig. 1C) whilst few copy number aberrations were detected elsewhere beyond those inherited from the parental cell line (Fig. $\mathrm{S} 1 \mathrm{~B})$. Three of these resistant cell lines showed identical and characteristic patterns of amplification in and around the $B R A F$ locus that must stem from a pre-existing subpopulation in the parental cell line (Fig. $1 \mathrm{C}$ clones e-g). These three cell lines carried an associated amplification at 7q32 (128 Mb in Fig. 1C), and qPCR for the RBM28 gene at 7q32 in all 23 resistant cell lines detected amplification in these 3 cell lines and an additional 2 not tested by Beadchip array (Fig. S1C), meaning that 5/23 (22\%) resistant cell lines likely arose from a single pre-existing population. However, focal amplifications in the other resistant clones had unique breakpoints that could represent de novo amplifications (Fig. 1C clones a-d).

To determine whether selumetinib-resistant clones emerge from diverse pre-existing BRAFamplified subpopulations, we erased existing population heterogeneity by deriving clonal COLO205 cell lines. All ten clonal cell lines were sensitive to $1 \mu \mathrm{M}$ selumetinib, ceasing proliferation within 1 day of treatment, and all engendered proliferative drug resistant colonies upon prolonged selumetinib treatment. Remarkably, the time required for resistant colonies to appear in nine of the clonal cell lines was identical to parental COLO205 cells, with one clone being slower though not significantly so (Fig. 1D). This shows that pre-existing BRAFamplified cells in the parental COLO205 cell line are not required for and contribute little to the timing of selumetinib resistance. Furthermore, BRAF locus structure was different in each of eight resistant cell lines derived independently from 3 clonal COLO205 cell lines (Fig. 1E). Therefore, suppression of existing population heterogeneity does not alter the time required for acquisition of selumetinib resistance and unique de novo BRAF amplifications arise frequently ( $7 / 8$ cell lines). It is also worth noting that one resistant cell line showed no detectable amplification of $B R A F$, meaning that other mutations (or epigenetic changes) conferring resistance also arise de novo (Fig. 1E clone 4-b).

Together, these experiments reveal that amplification of $B R A F^{V 600 E}$ occurs frequently in COLO205 cells. Although pre-existing amplifications are present, these make a minor contribution to resistance, which emerges efficiently through de novo gene amplification.

Individual cells enter the cell cycle even under acute MEK inhibition

Inactivation of the ERK1/2 pathway by MEK inhibition induces $\mathrm{G} 1$ cell cycle arrest in BRAF V600E cell lines including COLO205 $(39,40)$. The treatment conditions used in this study result in growth arrest of COLO205 cells with no passaging required across six or more weeks in the presence of drug; instead, gradual cell death occurs over many weeks with remaining DTPs 
bioRxiv preprint doi: https://doi.org/10.1101/2021.03.23.436572; this version posted March 23, 2021. The copyright holder for this preprint (which was not certified by peer review) is the author/funder, who has granted bioRxiv a license to display the preprint in perpetuity. It is made available under aCC-BY 4.0 International license.

aggregating into large bodies from which resistant colonies often, but not always, emerge (Fig. 2A). De novo gene copy number amplifications normally arise through defective DNA replication, breakage-fusion-bridge cycles or extrachromosomal DNA mis-segregation, all of which are prevented by $\mathrm{G} 1$ arrest $(41,42)$. We therefore hypothesised that cells occasionally enter the cell cycle even in the presence of selumetinib, and that these cells are at risk of genome instability. Indeed, such events were recently reported during treatment with BRAF and EGFR inhibitors $(31,43)$.

To test this hypothesis, selumetinib-treated COLO205 cells were pulsed with the thymidine analogue ethynyl deoxyuridine (EdU), and labelled cells analysed by flow cytometry and imaging. A 4-hour pulse of EdU plus selumetinib applied after 24 hours pre-treatment with selumetinib alone labelled $4.9 \pm 0.3 \%$ of cells, compared to $43 \pm 4 \%$ of control cells (Fig $2 \mathrm{~B}$ ), confirming that a fraction of COLO205 cells continue to enter DNA replication in the presence of selumetinib. Such cells are detected at all times analysed up to at least 7 days after selumetinib application (Fig S2A), showing that cells continue to enter replication over prolonged drug treatment. The pre-existing BRAF-amplified subpopulation in the parental cell line may continue to replicate in drug, however equivalent assays in clonal COLO205 cell lines, which lack this subpopulation, revealed $4.7 \pm 2 \%$ EdU positive cells after 24 hours selumetinib compared to $44 \pm 6 \%$ in untreated controls (Fig. 2B), showing that EdU-positive cells do not represent the pre-existing BRAF amplified subpopulation. Staining both for EdU incorporation and the $\mathrm{G} 2$ marker Cyclin B1 (CCNB1) revealed that $~ 30 \%$ of EdU positive cells are also positive for CCNB1 in both selumetinib treated and untreated populations (Fig. 2C), and DAPI incorporation in EdU/CCNB1 double-positive cells is consistent with $4 \mathrm{n}$ genome content (Fig. $\mathrm{S} 2 \mathrm{~B}$ ). These data show that cells can escape the G1 arrest mediated by selumetinib and progress through the cell cycle. To ensure that escape from arrest is not unique to COLO205 cells, we analysed another $B R A F^{V 600 E}$ mutant colorectal cancer cell line, $\mathrm{HT} 29$, and observed a similar proportion of EdU positive cells (Fig. S2C). Similarly, we observed replicating cells after treatment of COLO205 cells with the MEKi trametinib, showing that escape from G1 and entry to replication is not unique to selumetinib treatment (Fig. S2D).

Stochastic escape from G1 arrest would explain the presence of EdU-positive cells, but so would a defined subpopulation remaining proliferative in the presence of selumetinib. To distinguish these possibilities, we first treated cells continuously for 11 days with EdU + selumetinib, during which time almost half the cells incorporated EdU (Fig. 2D). We then performed an EdU pulse-chase experiment, treating cells for 1 day with selumetinib alone, 1 day with selumetinib + EdU, then 5 days in selumetinib alone. Almost $10 \%$ of cells were EdUlabelled in the initial pulse, but during the 5-day chase this number decreased suggesting that the labelled subpopulation progressively die off rather than proliferate (Fig. 2E, bottom left). Furthermore, the EdU intensity did not decrease showing that EdU positive cells do not divide further (Fig. 2E, bottom right). It is important to note that EdU alone causes this arrest as we see the same effect in the absence of selumetinib (Fig. S2E); nevertheless, if cells arrest on $\mathrm{EdU}$ incorporation then the progressive increase in EdU-positive cells across time means that 
bioRxiv preprint doi: https://doi.org/10.1101/2021.03.23.436572; this version posted March 23, 2021. The copyright holder for this preprint (which was not certified by peer review) is the author/funder, who has granted bioRxiv a license to display the preprint in perpetuity. It is made available under aCC-BY 4.0 International license.

the population as a whole remains competent to escape G1 arrest and undergo DNA replication.

These results demonstrate that cells stochastically escape selumetinib mediated G1 arrest and progress through $S$ phase to G2. These DNA replication events provide an opportunity for de novo gene amplification, particularly if replication is sub-optimal.

Abnormal gene expression during cell cycle progression in selumetinib

A substantial number of genes involved in DNA replication are regulated indirectly by the ERK1/2 pathway, and suppression of ERK1/2 signalling through EGFR inhibition downregulates DNA repair genes $(35,44-46)$. MEK inhibition could therefore cause impaired and error prone DNA replication if not reversed on entry to $S$ phase, but transient ERK $1 / 2$ reactivation may coincide with escape from G1 arrest as reported for BRAF inhibition (43). We therefore assayed ERK1/2 activation by high-throughput imaging for ERK1/2 phosphorylated at T202/Y204 (pERK). As expected, a 24-hour treatment with selumetinib dramatically reduced $\mathrm{pERK}$ compared to untreated controls, with similar reductions observed in both EdU negative and EdU positive fractions (Fig. 3A). This shows that ERK1/2 are not reactivated in cells that have initiated DNA replication in the presence of selumetinib, and therefore replication may occur with improper gene expression.

Initial RNA-seq analysis across a 48-hour selumetinib treatment revealed vast transcriptomic changes in accord with the known G1 arrest and suppression of growth (Fig. 3B). Transcripts significantly downregulated across the time course segregated into a rapidly responding group enriched in signal transduction genes, particularly the MAPK pathway (47), and a slower responding group only substantially depleted 24 hours after selumetinib treatment. The latter group was highly enriched for ribosome biogenesis, cell cycle and DNA repair and replication genes, as expected for a population entering G1 arrest; however, these changes may be reversed on cell cycle re-entry.

To study the rare replicating cells, we developed a method for gene expression analysis after fixation, staining and sorting cells for intracellular markers (48). We then applied this method to enrich for CCNB1-positive G2 cells in selumetinib-treated and control populations, obtaining high quality RNA and mRNA-seq libraries (Fig. S3A and S3B). In accord with the pERK imaging data, CCNB1-positive cells in selumetinib did not re-induce genes repressed by MEK inhibition (Fig. S3C) (47), nor display the known transcriptomic signature of MEK functional output (Fig. S3D) (49). Therefore, even if replication is initiated by transient ERK1/2 activation this has no lasting impact on the transcriptome. We then filtered RNA-seq data for the 1561 transcripts significantly and substantially (>4-fold) differentially expressed between at least two of the four conditions (untreated/selumetinib-treated and CCNB1 -ve/+ve). These transcripts separated into 3 hierarchical clusters: cluster (i) genes are downregulated by selumetinib treatment irrespective of cell cycle stage; cluster (ii) genes are downregulated in selumetinib-treated CCNB1 negative cells but re-expressed in CCNB1 positive cells; cluster (iii) genes are upregulated on selumetinib treatment irrespective of cell cycle (Fig. 3C). 
bioRxiv preprint doi: https://doi.org/10.1101/2021.03.23.436572; this version posted March 23, 2021. The copyright holder for this preprint (which was not certified by peer review) is the author/funder, who has granted bioRxiv a license to display the preprint in perpetuity. It is made available under aCC-BY 4.0 International license.

Cluster (i) contains well-characterised ERK1/2 targets including CCND1 (encoding Cyclin D1), DUSP4/5/6 and SPRED1/2. However, most prominent amongst GO enrichments for this cluster are terms relating to DNA replication, driven by transcripts encoding the entire $\mathrm{MCM}$ complex, CDC45, GINS components, replicative polymerase epsilon and alpha subunits, and other important replication proteins including PCNA, FEN1, TIPIN and CLSPN. Many of these genes are transcriptionally activated by E2F transcription factors (50-52), and transcripts encoding E2F1 and E2F2 also feature in this cluster as do the E2F targets CCNE1 and CCNE2 encoding cyclins E1 and E2. Although the proteins encoded by these transcripts would have already performed their replicative function before accumulation of CCNB1 at G2, the fact that all of these transcripts are dramatically lower in selumetinib-treated G2 cells compared to untreated G2 cells shows that the regulation of these genes is impaired by selumetinib. In contrast, cluster (ii) transcripts are downregulated in the bulk selumetinib-treated population but induce to normal levels in $\mathrm{G} 2$ cells. GO analysis of this cluster reveals strong enrichments for mitotic cell cycle and terms associated with chromosome segregation, microtubule organisation and centromeric chromatin deposition. This cluster also includes genes for DNA repair factors involved in processing stalled and damaged replication forks such as $B R C A 2$, $B L M, G E N 1$ and $P O L Q$, showing that chromosome segregation and DNA repair genes can be induced as required in $\mathrm{G} 2$ irrespective of ERK1/2 signalling. Cluster (iii) contained genes in a wide range of functional categories and was not significantly enriched for any GO category.

Although this analysis demonstrates that key replication genes are mis-expressed during cells escaping selumetinib-induced G1 arrest, profiling CCNB1-positive cells would miss a transient upregulation of transcripts during $S$ phase. To address this, we optimised a protocol for recovering RNA from sorted EdU-positive cells that provided RNA of sufficient quality for mRNA-seq library construction, although RNA integrity was lower than we would normally use since Click-labelling degrades RNA (Fig. S3E, S3F). Reassuringly, transcript levels in EdUpositive cells from selumetinib-treated and control populations were similar to CCNB1positive cells across the differentially expressed clusters (Fig. S3F), with expected differences such as CCNB1 mRNA being 4-fold lower in EdU positive than CCNB1-positive fractions and CCNE1 and CCNE2 (unstable mRNAs encoding Cyclin E) being higher. However, a subset of the genes in cluster (i) is upregulated in EdU-positive selumetinib-treated cells compared to CCNB1-positive or negative cells, showing that transient re-expression does occur in S phase (Fig. S3F upper panel, highlighted in orange). This set includes mRNAs for E2F1, E2F2 and key DNA replication proteins including CLSPN, POLE2 and POLA2 (Fig. 3D, upper genes). In contrast, other genes vital for DNA replication fidelity remained repressed in the EdU-positive fraction including the MCM complex, FEN1, TIPIN and PCNA. Notably, deficiencies in any one of these have been shown to cause genome instability (53-57) (Figure 3D, lower genes).

Together, these data show that in the presence of selumetinib, a fraction of cells can enter $\mathrm{S}$ phase without reactivation of ERK1/2 signalling. Although many cell cycle-regulated genes are induced to normal levels as cells enter the cell cycle, a subset of genes encoding key 
bioRxiv preprint doi: https://doi.org/10.1101/2021.03.23.436572; this version posted March 23, 2021. The copyright holder for this preprint (which was not certified by peer review) is the author/funder, who has granted bioRxiv a license to display the preprint in perpetuity. It is made available under aCC-BY 4.0 International license.

Acquisition of MEKi resistance during DNA replication in drug

Channathodiyil et al.

replication factors remain downregulated throughout the cell cycle. This increases the chance of DNA replication errors that may give rise to de novo genome rearrangements.

Replication during MEK inhibition facilitates the emergence of drug resistance

These changes in gene expression might suggest a rapid shift to a mutagenic state upon selumetinib application, but proteins such as MCMs and PCNA are long-lived and so levels only decline slowly (58-60). We applied high-throughput imaging to quantify MCM2 and MCM7 in EdU-negative and positive cells over 1-week and 3-week time-courses (Fig. 4A and $\mathrm{S} 4 \mathrm{~A}$ ), and observed that levels of both proteins decreased over the first week in the EdUnegative (G1) population as predicted, then remained stable for the following 2 weeks. Prior to selumetinib treatment, levels of MCM2 and MCM7 were similar in EdU-negative (G1) and EdU-positive (S and G2) cells (Fig. 4A, untreated), but entry to $S$ phase in the presence of selumetinib must involve synthesis of MCM proteins as MCM2 and MCM7 were substantially more abundant in EdU-positive than EdU-negative cells (Fig. 4A, 1-3 weeks). This may nonetheless be insufficient to maintain normal DNA replication as MCM7 is still less abundant under selumetinib than in normal S phase (Fig. 4A left panel, note that in EdU-positive cells, the median MCM7 level for each of the selumetinib-treated time points lies in the bottom quartile of MCM7 levels in untreated cells). Furthermore MCM2 is expressed to a higher level than in untreated cells meaning that the abundance of the stoichiometric MCM complex members is unbalanced (Fig. 4A right panel, note that for EdU-positive cells, the median MCM2 level for each of the selumetinib-treated time points lies in the top quartile of MCM2 levels in untreated cells).

These changes in protein level are subtle, but sub-optimal MCM protein levels and imbalances are known to cause genome instability and sensitivity to replication stress $(55,56,61,62)$, raising the hypothesis that DNA replication during long-term drug treatment would carry a higher frequency of de novo DNA rearrangements, including gene amplifications such as we observe at BRAF. It follows that if the frequency with which cells enter DNA replication during drug treatment can be reduced then the formation of selumetinib resistant clones that result from de novo gene amplification events should be retarded.

Reduced CCND1 expression caused by selumetinib treatment (Fig. S4B) must decrease the activity of CCND1-CDK4/6, reducing Rb phosphorylation and impairing cell cycle entry (63, 64). Recent studies have shown that MEKi can combine well with CDK4/6i in melanoma to further suppress proliferation $(65,66)$ so we examined this combination in our colorectal cancer model. Indeed the combination of selumetinib with a low dose of the CDK4/6i palbociclib further reduced the already low levels of phosphorylated Rb (pRb) (Fig. 4B). In contrast, this dose of palbociclib had no discernible effect on $\mathrm{pRb}$ in the absence of selumetinib, nor was the total level of $\mathrm{Rb}$ altered by palbociclib in the presence or absence of selumetinib (Fig. 4B). EdU incorporation assays confirmed that this dose of palbociclib had no impact on entry to the cell cycle in the absence of selumetinib but further reduced the fraction of EdU positive cells in the presence of selumetinib 10-fold (Fig. 4C, 4D). Furthermore, this concentration of palbociclib had no effect on cell proliferation or colony formation by parental 
bioRxiv preprint doi: https://doi.org/10.1101/2021.03.23.436572; this version posted March 23, 2021. The copyright holder for this preprint (which was not certified by peer review) is the author/funder, who has granted bioRxiv a license to display the preprint in perpetuity. It is made available under aCC-BY 4.0 International license.

COLO205 cells in the absence of selumetinib (Fig. S4C, S4D). Therefore, palbociclib acts in combination with selumetinib to decrease the population of replicating cells.

We then compared the time taken for proliferating drug-resistant colonies to emerge in cultures treated with selumetinib alone or with a combination of selumetinib and low dose palbociclib in the parental COLO205 cell line and 4 single cell-derived clones. Resistant colonies formed in $86 \%$ of cultures, and average BRAF amplifications were equivalent for resistant cell lines derived under both conditions showing that palbociclib does not prevent acquisition of resistance through BRAF amplification (Fig. S4E). Curiously, although all tested resistant cell lines derived on selumetinib alone carried $B R A F$ amplifications, a subset of those derived on the combination did not, suggesting alternative paths to resistance become important (Fig. S4D). However, the addition of palbociclib slowed the emergence of resistant clones substantially and significantly in all 5 cell lines, delaying the median time to resistance (where measurable) by three to eight weeks (Fig. 4E, 4F). We used a Cox Proportional-Hazards Model to quantify the overall effect of low dose palbociclib in combination with selumetinib compared to selumetinib alone, and found that palbociclib reduced the risk of resistance by $78 \%$ with $p=1.6 \times 10^{-11}$. Differences between the COLO205 cell lines had no significant effect on palbociclib action ( $p=0.93$ ), even though there was a significant difference between the cell lines in acquisition of resistance in general $\left(p=1.1 \times 10^{-10}\right)$. For example, clone 1 was slow to obtain resistance here as in Fig. 1D $\left(p=5.5 \times 10^{6}\right)$ but took even longer to develop resistance under combined treatment with palbociclib.

Taken together, our experiments show that in most cases selumetinib resistance in COLO205 cells does not arise from cells with pre-existing amplifications; rather, the majority of gene amplifications causing resistance arise de novo through DNA replication, most likely due to the progressive loss of key replication factors caused by inhibition of ERK1/2 signalling.

\section{Discussion}

Here using $\mathrm{BRAF}^{\mathrm{V} 600 \mathrm{E}}$-mutant colorectal cancer cells addicted to ERK1/2 signalling we show that de novo BRAF amplifications arise in selumetinib-treated populations with remarkable efficiency. Cells under continuous selumetinib exposure stochastically escape G1 arrest and enter $\mathrm{S}$ phase but do so without inducing a subset of replication factors critical for error-free DNA replication. Escape from $\mathrm{G} 1$ arrest is vulnerable to otherwise inert doses of CDK4/6i such that a MEKi+CDK4/6i combination suppresses DNA replication during selumetinib treatment, which retards the emergence of resistance and links de novo gene amplification to DNA replication in drug.

\section{Acquisition of resistance through replication in the presence of drug}

The sporadic entry of cells into S phase during drug-imposed G1 arrest has been reported in various cell culture systems $(31,43)$, and downregulation of high fidelity replication and repair 
bioRxiv preprint doi: https://doi.org/10.1101/2021.03.23.436572; this version posted March 23, 2021. The copyright holder for this preprint (which was not certified by peer review) is the author/funder, who has granted bioRxiv a license to display the preprint in perpetuity. It is made available under aCC-BY 4.0 International license.

Acquisition of MEKi resistance during DNA replication in drug

Channathodiyil et al.

genes has been observed in drug-arrested $G 1$ populations $(33,35)$, suggesting that DNA replication could invoke a general increase in mutability. Here we examined gene expression changes in cells treated with MEKi that escape G1 and progress to S and G2, the cell cycle phases in which DNA replication and high-fidelity DNA repair factors are active. Our analysis of bulk populations treated with selumetinib support previous observations, but we find that many genes important for homologous recombination and repair of defective replication intermediates are re-induced to normal levels in S and G2, likely compensating for any deficit in the G1-arrested population. Similarly, selumetinib-treated cells in G2 show normal expression of genes involved in chromosome segregation. This suggests that even during MEKi treatment, the main mechanisms ensuring faithful transmission of genetic material are normal irrespective of gene expression in the G1-arrested population.

However, a subset of genes encoding critical replication factors remain substantially underexpressed throughout the cell cycle in MEKi-treated cells. The disconnect between mRNA and protein levels is well recognised (67), but sustained downregulation of mRNAs encoding critical cell cycle proteins in cells arrested in $\mathrm{G} 1$ for days or weeks must reduce resting protein levels, an effect we clearly observe for MCM2 and MCM7. Although additional protein is synthesised in the cells that enter $\mathrm{S}$ phase, this does not result in normal balanced protein levels, and may occur too late to offset the deficiency in resting MCM protein levels as MCM complexes need to be loaded during $\mathrm{G} 1$ or even the preceding M-phase $(68,69)$. Disruption of MCM complex gene expression is mutagenic in itself $(55,56,61,62)$, but the effects on protein level are subtle, and we consider that replication in MEKi-treated cells would be impaired through the sum of small defects in expression of many replication proteins, rather than through MCM proteins alone. This would undermine the fidelity of ongoing DNA replication in drug, providing the conditions for de novo resistance mutations.

Mutability under stress is well characterised in bacteria and has been repeatedly observed in yeast (70-73). However, it is hard to prove that such events result from defined programmes that have emerged through selective evolution, against the null hypothesis that mutagenesis is an emergent property of normal maintenance and proliferation systems becoming compromised under stress. We would therefore hesitate to label genome instability caused by under-expression of replication proteins as a mutagenic response, though our study provides strong support for the suggestion that non-genotoxic drug treatment can increase mutation rate and drive the de novo emergence of resistance. Whether mutagenesis is intentional or not, our study and others addressing drug-induced mutation provide grounds for optimism that resistance to targeted chemotherapeutics is preventable, since mutational mechanisms that act during chemotherapy can be characterised and suppressed.

de novo gene amplification promotes reproducible emergence of resistance

Acquiring the correct $B R A F^{V 600 E}$ copy number presents a challenge: low BRAF V600E copy numbers do not provide sufficient ERK1/2 activity for growth but excessive BRAF ${ }^{\mathrm{V} 600 \mathrm{E}}$ leads to 
bioRxiv preprint doi: https://doi.org/10.1101/2021.03.23.436572; this version posted March 23, 2021. The copyright holder for this preprint (which was not certified by peer review) is the author/funder, who has granted bioRxiv a license to display the preprint in perpetuity. It is made available under aCC-BY 4.0 International license.

senescence or apoptosis (38). Therefore, the BRAF copy number window for proliferation at a given MEKi dose is narrow and, given that pre-existing drug resistant cells are by definition rare, it is unlikely that one or more cells with the required BRAF copy number would always exist in a cell population prior to treatment. In contrast, stochastic de novo gene amplification events can eventually encompass all possible copy numbers, such that one or more cells in the population will always acquire the optimal BRAF copy number allowing maximum proliferation. This means that de novo acquisition of resistance is much more robust than resistance arising through random pre-existing mutations.

One puzzling feature of drug tolerant persister (DTP) cells that survive for long periods in the presence of chemotherapeutics such as selumetinib is the sharp transition between drug tolerance and proliferation. The bulk population does not slowly re-acquire the ability to proliferate in drug; instead individual colonies of rapidly dividing cells suddenly appear after weeks or months of apparent stasis, requiring a marked return to proliferation in a very small number of cells (24-27). The mechanism we propose explains this property; occasional cell division events would not be noticeable in long-term drug treated cultures as these are offset by ongoing cell death. However, if each replication event carries a risk of de novo gene amplification then each cell has a chance of acquiring the correct amplification to allow proliferation during a sporadic replication event. Gene amplifications arising in this manner would manifest as a sudden return of a single cell to proliferation, with an average time-toresistance defined by the frequency of DNA replication events in drug and the extent to which drug treatment reduces the fidelity of replication.

Indeed, reducing the frequency of replication events with a low dose of palbociclib delayed the formation of resistant clones. Palbociclib was designed as an inhibitor of the CCND1CDK4/6 complex (74), and a simple explanation of this effect would be that low dose palbociclib is sufficient to inhibit residual CCND1-CDK4 complex present after MEKi. However, biochemical analysis shows that palbociclib does not inhibit the active p27-CCND1-CDK4 complex but rather binds to the CDK4 monomer and prevents assembly of p27-CCND1-CDK4 (75). In doing so, palbociclib not only prevents CCND1-CDK4 activity but also increases the free pool p27, which inhibits $\operatorname{CDK} 2(76,77)$. Therefore, the MEKi + palbociclib combination is complex and may act through both MEKi reducing expression of CCND1 to prevent assembly of active CCND1-CDK4 complexes and palbociclib causing a more complete inhibition of all CDK4 by preventing assembly of all possible CDK4/6-containing complexes, thereby releasing p27 to inhibit CDK2. In any case, the MEKi + palbociclib combination is extremely effective in preventing sporadic entry to $S$ phase, and delays the emergence of de novo proliferative clones carrying $B R A F$ amplifications.

Overall, our study shows that pathways to de novo mutation can be mechanistically defined, and present vulnerabilities that can be specifically targeted to slow or stop the acquisition of drug resistance. 
bioRxiv preprint doi: https://doi.org/10.1101/2021.03.23.436572; this version posted March 23, 2021. The copyright holder for this preprint (which was not certified by peer review) is the author/funder, who has granted bioRxiv a license to display the preprint in perpetuity. It is made available under aCC-BY 4.0 International license.

Acquisition of MEKi resistance during DNA replication in drug

Channathodiyil et al.

\section{Materials and Methods}

Cell culture and drug treatment

COLO205 and HT29 colorectal cancer cell lines were provided by the laboratory of Dr. Simon J Cook at the Babraham Institute. Cells were cultured in RPMI-1640 (COLO205) or McCoy's 5A (HT29) media supplemented with $10 \%(\mathrm{v} / \mathrm{v})$ foetal bovine serum, penicillin $(100 \mathrm{U} / \mathrm{mL})$, streptomycin $(100 \mathrm{mg} / \mathrm{mL})$ and $2 \mathrm{mM}$ glutamine at $37^{\circ} \mathrm{C}$ in a humidified incubator with $5 \%$ (v/v) CO2. Media and reagents were purchased from ThermoFisher Scientific, UK. Cells were routinely tested for mycoplasma contamination using the MycoAlert ${ }^{\mathrm{TM}}$ Mycoplasma Detection Kit (Lonza, LT07-418). To derive COLO205 cells resistant to selumetinib or to combined treatment with selumetinib and palbociclib (Selleckchem, S111614), cells were seeded in $25 \mathrm{~cm}^{2}$ cell culture flasks $\left(1 \times 10^{6}\right.$ cells per flask) or 6 -well plates $\left(0.5 \times 10^{6}\right.$ cells per well) in growth media and treated 24 hours later with the concentrations of drugs indicated in the figure legends. Media and drug were changed weekly until colonies ( $\geq 50$ cells) of proliferating cells were formed in culture.

Cell line identity was validated based on RNA-seq data generated in this work using Cell Line Sleuth, developed by Simon Andrews of the Babraham Institute Bioinformatics Facility (https://github.com/s-andrews/celllinesleuth)

\section{Single cell sorting}

To generate single-cell derivatives of parental or selumetinib $(1 \mu \mathrm{M})$-resistant (C6244-R) COLO205 cell lines, cells were harvested by trypsinisation, centrifuged ( $300 \times \mathrm{g}$ for 5 minutes) and the cell pellet resuspended in fresh media or media containing selumetinib $(1 \mu \mathrm{M})$ respectively at a cell density of $5 \times 10^{6}$ cells/ $\mathrm{mL}$. Cells were filtered by passage through a sterile, CellTrics $30 \mu \mathrm{m}$ filter (Sysmex, 04-004-2326) into $5 \mathrm{~mL}$ polypropylene round bottom tubes (Scientific laboratory supplies, 352063) to remove cell clumps and incubated with 1 $\mu \mathrm{g} / \mathrm{mL} 4$, 6-diamidino-2-phenylindole (DAPI) (Sigma, D9542) to allow exclusion of dead cells. DAPI-negative cells were then sorted into 96-well plates containing $100 \mu \mathrm{L}$ fresh media (parental cells) or media containing selumetinib $(1 \mu \mathrm{M})$ (selumetinib resistant cells) using a $100 \mu \mathrm{m}$ nozzle on a BD FACSAria III sorter (BD Biosciences, UK).

EdU staining and immunofluorescence for imaging

Cells were seeded on glass coverslips in 6-well plates and treated 24 hours later with $1 \mu \mathrm{M}$ Selumetinib followed by addition of 2 or $10 \mu \mathrm{M}$ EdU as described in the figure legends. Cells were washed once in PBS, fixed with $4 \%$ formaldehyde in PBS for 10 minutes, and permeabilised with $0.5 \%$ Triton X-100 in PBS for 30 minutes at room temperature (RT). Cells were then washed in 3\% BSA and EdU incorporation detected by incubation in click reaction cocktail (43 $\mu \mathrm{L}$ Component D, $387 \mu \mathrm{L}$ water, $20 \mu \mathrm{L} \mathrm{CuSO}_{4}, 50 \mu \mathrm{L}$ reaction buffer additive (43 $\mu \mathrm{L} 10 \mathrm{x}$ reaction buffer additive $+387 \mu \mathrm{L}$ water) and $1.2 \mu \mathrm{L}$ Alexa Fluor dye) (Click-iT ${ }^{\mathrm{TM}} \mathrm{EdU}$ 
bioRxiv preprint doi: https://doi.org/10.1101/2021.03.23.436572; this version posted March 23, 2021. The copyright holder for this preprint (which was not certified by peer review) is the author/funder, who has granted bioRxiv a license to display the preprint in perpetuity. It is made available under aCC-BY 4.0 International license.

Acquisition of MEKi resistance during DNA replication in drug

Channathodiyil et al.

Alexa Fluor ${ }^{\mathrm{TM}} 594$ imaging kit, Thermo Fisher Scientific, C10339) for 30 minutes at RT in dark. The reaction cocktail was removed and cells washed in 3\% BSA in PBS and mounted in Vectashield antifade mounting medium with DAPI (Vector laboratories, H1200).

For combined detection of EdU incorporation and pERK, MCM2 and MCM7 levels by highthroughput imaging, $1 \times 10^{4}$ cells were seeded per well in 96-well imaging plates (Cell carrier96, Perkin Elmer) and treated 24 hours later with $1 \mu \mathrm{M}$ Selumetinib for the duration indicated in the figure legends before addition of $10 \mu \mathrm{M}$ EdU for 4 hours. Cells were fixed in $4 \%$ formaldehyde in PBS, washed with PBS and permeabilised with $100 \%$ methanol for 10 minutes at $-20^{\circ} \mathrm{C}$. Cells were then washed twice in PBS and EdU labelled using a Click-iT ${ }^{\mathrm{TM}} \mathrm{EdU}$ Alexa Fluor ${ }^{\mathrm{TM}} 647$ HCS assay kit (Thermo Fisher Scientific, C10357) following manufacturer's instructions. For antibody labelling, cells were incubated in blocking solution ( $5 \%$ normal goat serum and 2\% BSA in PBS) for 1 hour at RT, followed by incubation with antibodies against PERK, MCM2 or MCM7 diluted 1:400, 1:400 and 1:200 respectively in 1\% BSA and $0.3 \%$ Triton $\mathrm{X}-100$ in $\mathrm{PBS}$ at $4^{\circ} \mathrm{C}$ overnight. Antibody diluent without primary antibody was added to background control wells. Cells were washed 3 times in PBS and incubated with secondary antibody (Alexa Fluor 488 donkey anti-rabbit antibody, Thermo Fisher Scientific, A21206) diluted 1:1000 in 1\% BSA and 0.3\% Triton X-100 in PBS for 1 hour at RT in dark. Cells were washed 3 times in PBS and incubated in $1 \mu \mathrm{g} / \mathrm{mL}$ DAPI (Sigma, D9542) in PBS for 10 minutes at RT. Cells were washed twice in PBS and $100 \mu \mathrm{L}$ PBS added to each well for imaging. Cells were imaged using an INCell Analyser 6000 Microscope using a 10x objective lens imaging 6 fields (for $\mathrm{pERK}$ ) or 9 fields (for MCM2 and MCM7) per well. Details of antibodies are provided in Table S4.

\section{Immunolabelling and EdU staining for flow cytometry}

Quantitative detection of EdU incorporation was performed using a Click-iT ${ }^{\mathrm{TM}}$ EdU Alexa Fluor $^{\text {TM }} 488$ Flow cytometry kit (Thermo Fisher Scientific, C10420) following the manufacturer's instructions. Briefly, cells were incubated with 2 or $10 \mu \mathrm{M}$ EdU for the time indicated in figure legends. Cells were trypsinised, collected by centrifugation ( $300 \times g$ for 5 minutes at RT) and washed once in PBS. Cells were fixed with Click-iT ${ }^{\circledR}$ fixative for 15 minutes at RT and washed in excess $1 \%$ BSA in PBS. Cells were permeabilised in $100 \mu \mathrm{L} 1 \mathrm{x}$ saponinbased permeabilisation and wash reagent for 15 minutes or ice-cold $100 \%$ methanol (for combined antibody labelling and EdU staining) while vortexing gently for 30 minutes followed by incubation in $250 \mu \mathrm{L}$ click reaction mix (219 $\mu \mathrm{L} \mathrm{PBS,} 5 \mu \mathrm{L} \mathrm{CuSO}_{4}, 25 \mu \mathrm{L} 1 x$ buffer additive, $1.25 \mu \mathrm{L}$ Alexa Fluor dye) for 30 minutes at RT in dark. Cells were washed in excess $1 x$ saponinbased permeabilisation and wash reagent ( $300 \times g$ for 5 minutes). For antibody labelling, cells were blocked for 30 minutes in 1\% BSA in PBS, followed by incubation for 1 hour at RT with primary antibody diluted in 1\% BSA in PBS. Cells were then washed in PBS and incubated with secondary antibody for 1 hour at RT in dark, after which they were washed again in PBS. Cells were then processed for DNA staining in $1 \mu \mathrm{g} / \mathrm{mL}$ DAPI diluted in $100 \mu \mathrm{L} 1 \mathrm{x}$ saponin-based permeabilisation and wash reagent. Cells were filtered to remove aggregates by passage through sterile, $30 \mu \mathrm{m}$ CellTRics filter (Sysmex, 04-004-2326) into $5 \mathrm{~mL}$ polystyrene round- 
bioRxiv preprint doi: https://doi.org/10.1101/2021.03.23.436572; this version posted March 23, 2021. The copyright holder for this preprint (which was not certified by peer review) is the author/funder, who has granted bioRxiv a license to display the preprint in perpetuity. It is made available under aCC-BY 4.0 International license.

Acquisition of MEKi resistance during DNA replication in drug

Channathodiyil et al.

bottom tubes. Samples were analysed on a Fortessa (BD Biosciences, UK) flow cytometer with a minimum of 10,000 events acquired per sample.

To isolate cells by flow cytometry following EdU or CCNB1 staining, COLO205 cells were seeded at a density of $1 \times 10^{6}$ cells in $25 \mathrm{~cm}^{2}$ cell culture flasks and treated 24 hours later with DMSO or $1 \mu \mathrm{M}$ selumetinib and/or with $10 \mu \mathrm{M}$ EdU as indicated in the figure legends. Cells were then processed for immunofluorescence and flow sorting as previously described (48). Briefly, cells were harvested by trypsinisation, washed once with PBS and fixed in $3 \%$ glyoxal solution ( $2.8 \mathrm{ml}$ water, $0.79 \mathrm{ml} 100 \%$ ethanol, $0.31 \mathrm{ml} 40 \%$ glyoxal (Sigma, 50649) and $30 \mu \mathrm{l}$ acetic acid; $\mathrm{pH}$ adjusted to 4-5 with a few drops of $1 \mathrm{M} \mathrm{NaOH}$ ) and 1:25 RNasin Plus (Promega, N261B) for 15 minutes on ice. Cells were washed in PBS with 1:100 RNasin Plus by centrifugation at $2000 \times g$ for 3 minutes at $4^{\circ} \mathrm{C}$. Cell pellet was resuspended in $100 \mu \mathrm{L}$ ice-cold methanol ( $100 \% \mathrm{v} / \mathrm{v}$ ) with 1:25 RNasin Plus (added drop by drop while gently vortexing cells), incubated on ice for 30 minutes and again washed in PBS with 1:100 RNasin Plus by centrifugation at $2000 \times g$ for 3 minutes at $4^{\circ} \mathrm{C}$. For EdU staining, cells were incubated in a modified click reaction cocktail (209 $\mu \mathrm{L}$ PBS, $5 \mu \mathrm{L} \mathrm{CuSO}_{4}, 25 \mu \mathrm{L} 1 \mathrm{M}$ L-ascorbic acid (Sigma,

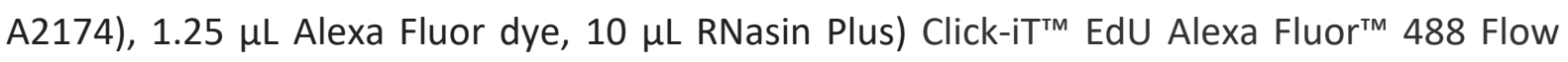
cytometry kit (Thermo Fisher Scientific, C10420) and incubated on ice for 30 minutes in dark. Following incubation, cells were washed in 1\% BSA in PBS and 1:100 RNasin Plus before they were processed for DNA staining. For CCNB1 staining, cells were incubated with primary antibody against CCNB1 (diluted 1:200 in 1\% BSA in PBS and 1:25 RNasin Plus) for 1 hour on ice. Cells were washed in PBS with 1:100 RNasin Plus and incubated in fluorescent tagged secondary antibody (diluted 1:1000 in 1\% BSA in PBS with 1:25 RNasin Plus) for 30 minutes on ice in dark. Cells were washed again in 1\% BSA in PBS with 1:100 RNasin Plus and cell pellet resuspended in $200 \mu \mathrm{L} 1 \%$ BSA in PBS with 1:100 RNasin Plus. For DNA staining, cells were incubated in $1 \mu \mathrm{g} / \mathrm{mL}$ DAPI in PBS. Cells were sorted using a $100 \mu \mathrm{m}$ nozzle on a BD FACSAria III sorter (BD Biosciences, UK) into 1.5ml Eppendorf tubes coated with RNasin plus.

\section{RNA extraction and mRNA-seq library preparation}

Cells grown in monolayers were trypsinised, collected by centrifugation (300 $\mathrm{x} g$ for 5 minutes) and washed once in PBS. Cells sorted by flow cytometry were pelleted by centrifugation (2000 x $g$ for 3 minutes). Cells were lysed in $1 \mathrm{~mL}$ TRI reagent Sigma, T9424) until a homogeneous lysate was obtained and allowed to stand for 10 minutes at RT. For RNA isolation from cells sorted by flow cytometry, $1 \mathrm{~mL}$ TRI reagent was added to cells after they were pelleted by centrifugation $\left(2000 \times g\right.$ for 3 minutes at $4^{\circ} \mathrm{C}$ ). The lysate was centrifuged at $12000 \times g$ for 15 minutes at $4{ }^{\circ} \mathrm{C}$ and the upper aqueous phase containing RNA was collected in fresh tubes to which $0.5 \mathrm{~mL}$ 2-propanol was added, mixed well and allowed to stand for 10 minutes. For RNA extraction from $<50,000$ cells, $1 \mu \mathrm{L}$ GlycoBlue coprecipitant $15 \mathrm{mg} / \mathrm{mL}$ (ThermoFisher scientific, AM9516) was added to the mixture to aid the visibility of RNA pellets. The resulting mixture was centrifuged $\left(12,000 \times \mathrm{g}\right.$ for 10 minutes at $\left.4{ }^{\circ} \mathrm{C}\right)$ and supernatant discarded. RNA pellets were washed in $1 \mathrm{~mL} 75 \%(\mathrm{v} / \mathrm{v})$ ethanol by centrifugation 
bioRxiv preprint doi: https://doi.org/10.1101/2021.03.23.436572; this version posted March 23, 2021. The copyright holder for this preprint (which was not certified by peer review) is the author/funder, who has granted bioRxiv a license to display the preprint in perpetuity. It is made available under aCC-BY 4.0 International license.

at $7,500 \times g$ for 5 minutes at $4{ }^{\circ} \mathrm{C}$. Pellets were then air-dried for 5-10 minutes and resuspended in 10-20 $\mu \mathrm{L}$ nuclease-free water.

RNA integrity was assessed by electrophoresis on a denaturing agarose gel and/or a Bioanalyzer 6000 pico chip (Agilent 5067-1513). mRNA seq libraries were prepared using the NEBNext ultra (NEB E7420S) (or ultra II) Directional RNA kit (NEB E7760S) with the NEBNext Poly(A) mRNA Magnetic Isolation Module (NEB E7490S), following the protocol provided by the manufacturer with the exception that two successive 0.9x AMPure purifications were performed on the final amplified libraries. Libraries were amplified for 12-14 cycles. Library quality was assessed on a Bioanalyzer 2100 using High Sensitivity DNA chips (Agilent 50674626) and quantification performed with a KAPA Library Quantification Kit (Roche, KK4844). Libraries were sequenced by the Babraham Institute Next Generation Sequencing Facility on an Illumina HiSeq2500 in Rapid Run 50bp Single End mode.

mRNA-seq data analysis

After adapter and quality trimming using Trim Galore (v0.5.0), RNAseq data was mapped to human genome GRCh38 using HISAT2 v2.1.0 (78) by the Babraham Institute Bioinformatics Facility. Mapped data was imported into SeqMonk v1.47.0 (https://www.bioinformatics.babraham.ac.uk/projects/seqmonk/) and normalised to total read count. DESeq2 analyses (79) was performed within SeqMonk using a p-value cut-off of 0.01 , and significantly different genes were further filtered for genes with $>4$-fold difference in at least one comparison. Hierarchical clustering analysis was performed using SeqMonk, and GO analysis of individual clusters performed using GOrilla (http://cblgorilla.cs.technion.ac.il/) $(80,81)$. Quoted p-values for GO analysis are FDR-corrected according to the Benjamini and Hochberg method (q-values from the GOrilla output), for brevity only the order of magnitude rather than the full q-value is given (82).

All sequencing data is available through GEO accession: GSE168604.

$D N A$ extraction and $q P C R$

Genomic DNA from cells was extracted using a Qiagen DNeasy Blood and Tissue kit (Qiagen, 69504), according to the manufacturer's instructions. DNA (2 $\mu \mathrm{g})$ was digested with a restriction enzyme that does not cut the amplicons (EcoRI, NEB R3101) by incubation at $37^{\circ} \mathrm{C}$ for 1 hour. The digested products were purified using a QIAquick PCR purification kit (Qiagen, 28106) according to the manufacturer's instructions. For each qPCR reaction, $4 \mu \mathrm{L}$ purified DNA $(1 \mu \mathrm{g} / \mu \mathrm{L})$ was mixed with $5 \mu \mathrm{L} 2$ x Maxima SYBR mix, $0.2 \mu \mathrm{l}$ each of forward and reverse primers $(10 \mu \mathrm{M})$ and $0.6 \mu \mathrm{l}$ nuclease-free water. The PCR cycling conditions were initial denaturation at $95^{\circ} \mathrm{C}$ for 10 minutes, followed by 40 cycles of denaturation at $95^{\circ} \mathrm{C}$ for 15 seconds and extension at $60^{\circ} \mathrm{C}$ for $1 \mathrm{~min}$ on the Bio-Rad CFX qPCR machine (Bio-Rad, UK). Data were analysed with CFX manager software v.3.1. Details of primer sequences are provided in Table S5.

\section{CNV microarray}


bioRxiv preprint doi: https://doi.org/10.1101/2021.03.23.436572; this version posted March 23, 2021. The copyright holder for this preprint (which was not certified by peer review) is the author/funder, who has granted bioRxiv a license to display the preprint in perpetuity. It is made available under aCC-BY 4.0 International license.

Total DNA from cells was isolated using a Qiagen DNeasy Blood and Tissue kit (Qiagen, 69504) and DNA quality was assessed using a Nanodrop 2000 Spectrophotometer (ThermoFisher Scientific, UK) to determine A260/A280 and A260/A230 ratios, and by electrophoresis on 1\% agarose gel to confirm absence of degradation. DNA quantity was estimated using a Quant-iT PicoGreen dsDNA assay kit (ThermoFisher Scientific, P7589) following instructions provided by the manufacturer. DNA samples (200 ng per sample) were processed by Cambridge genomics services (Department of Pathology, Cambridge) for hybridisation onto cytoSNP $850 \mathrm{~K}$ beadchips (Illumina) according to the manufacturer's instructions. The raw intensity data files (.idat) were converted to genotype call files (.gtc) using Beeline software version 4.5 then imported to BlueFuse Multi software version 4.5 and analysed using BlueFuse algorithm with default settings ( 10 contiguous markers for CNV and 500 contiguous markers for loss of heterozygosity (LOH)). The cluster and manifest files used for processing Illumina CytoSNP850K v1.1 were CytoSNP-850Kv1-1_iScan_C1_ClusterFile.egt and CytoSNP-850Kv11_iScan_C1.bpm respectively and CytoSNP-850Kv1-2_iScan_B1_ClusterFile.egt and CytoSNP850Kv1-2_iScan_B3.bpm respectively for Illumina CytoSNP-850K v1.2 beadchips. The annotation file used for the analysis was BG_Annotation_Ens74_20180801.db (genome build 37).

All array data is available through GEO accession: GSE168604.

Protein extraction and Western blot

Preparation of cell lysates for SDS-PAGE and western blotting were performed as previously described (38). Cells grown in $25 \mathrm{~cm}^{2}$ cell culture flasks were detached using a cell scrapper, centrifuged (300 x $g$ for 3 minutes), washed once with PBS and lysed for 5 minutes with icecold TG lysis buffer (20 mM Tris- $\mathrm{HCl}$ (pH 7.4), $137 \mathrm{mM} \mathrm{NaCl}, 1 \mathrm{mM}$ EGTA, 1\% (v/v) Triton X$100,10 \%(\mathrm{v} / \mathrm{v})$ glycerol, $1.5 \mathrm{mM} \mathrm{MgCl}$, $50 \mathrm{mM} \mathrm{NaF}, 1 \mathrm{mM} \mathrm{Na}_{3} \mathrm{VO}_{4}, 5 \mu \mathrm{gL}^{-1}$ aprotinin, $10 \mu \mathrm{g} \mathrm{mL}-1$ leupeptin, $1 \mathrm{mM}$ phenylmethylsulfonyl fluoride (PMSF). Cell lysates were centrifuged for 10 minutes at $13,000 \times g$ at $4{ }^{\circ} \mathrm{C}$. Protein concentration was estimated by Bradford protein assay and absorbance read at $562 \mathrm{~nm}$ using a Pherastar plate reader (BMG labtech, UK). Protein samples were boiled for 5 minutes in $4 \mathrm{x}$ sample buffer ( $50 \mathrm{mM}$ Tris- $\mathrm{HCl}$ $(\mathrm{pH} 6.8), 2 \%(\mathrm{w} / \mathrm{v})$ SDS, $10 \%(\mathrm{v} / \mathrm{v})$ glycerol, $1 \%(\mathrm{v} / \mathrm{v}) \quad \beta$-mercaptoethanol, $0.01 \%(\mathrm{w} / \mathrm{v})$ bromophenol blue).

Total protein was subjected to electrophoresis through a 10\% SDS-PAGE gel for 4 hours at 75 $\mathrm{V}$, transferred to methanol-activated Immobilon-FL polyvinylidene difluoride (PVDF) membranes (Merck Millipore, Watford, UK) by wet transfer ( $0.2 \mathrm{M}$ glycine, $25 \mathrm{mM}$ Tris, 20\% (v/v) methanol) at $20 \mathrm{~V}$ overnight. Membranes were blocked with a blocking buffer ( $5 \%$ milk in Tris buffered saline and Tween 20 (TBST) (5\% (w/v) non-fat powdered milk, $10 \mathrm{mM}$ Tris- $\mathrm{HCl}$ ( $\mathrm{pH}$ 7.6), $150 \mathrm{mM} \mathrm{NaCl}, 0.1 \%(\mathrm{v} / \mathrm{v})$ Tween-20) for 1 hour at room temperature. Membranes were incubated with primary antibodies against CCND1, p27, phospho RB, RB and GAPDH as recommended in $5 \%$ milk in TBST or $5 \%$ BSA in TBST overnight at $4{ }^{\circ} \mathrm{C}$ with gentle agitation, after which they were washed in TBST ( $3 \times 10$ minute washes) and incubated with fluorescent tagged secondary antibodies (diluted 1:30,000 in 5\% milk in TBST) for 1 hour at room 
bioRxiv preprint doi: https://doi.org/10.1101/2021.03.23.436572; this version posted March 23, 2021. The copyright holder for this preprint (which was not certified by peer review) is the author/funder, who has granted bioRxiv a license to display the preprint in perpetuity. It is made available under aCC-BY 4.0 International license.

Acquisition of MEKi resistance during DNA replication in drug

Channathodiyil et al.

temperature in dark. Membranes were again washed ( $3 \times 10$ minute washes) before detection of bands using a Li-Cor Odyssey Imaging System (LI-COR Biosciences). Details of antibodies are provided in Table $\mathrm{S4}$.

Colony formation assay

COLO205 cells $\left(0.25 \times 10^{6}\right.$ cells/well) were seeded in 6-well plates and treated with $16 \mathrm{nM}$ palbociclib or DMSO only 24 hours later. Following 24 hours of treatment, cells were harvested by trypsinisation, counted by a Countess cell counter (ThermoFisher Scientific) and 100 cells seeded per well in 6-well plates in culture media each in the absence or presence of $16 \mathrm{nM}$ palbociclib in triplicates. Cells were incubated for 21 days, with media and drug replenished once a week. To stain colonies, cells were gently washed once in PBS and fixed and stained with crystal violet $(0.4 \%(\mathrm{w} / \mathrm{v})$, Sigma, C6158) in $50 \%$ methanol for at least 30 minutes. Excess stain was carefully removed from cells by gently immersing the culture plate several times in a trough filled with cold tap water. Plates were air-dried at room temperature.

\section{Statistical analysis}

Statistical tests were performed using GraphPad Prism v8.4.0, except the Cox ProportionalHazards Model, which was implemented in RStudio v1.2.5033. Code is available on GitHub https://github.com/segondsa/resistant-colonies

\section{Acknowledgements}

We greatly appreciate the assistance of Simon Andrews of the BI Bioinformatics facility for coding, Hanneke Okkenhaug of the BI Imaging facility for high-throughput imaging analysis, BI Flow, BI Next Generation Sequencing, BI Bioinformatics and BI Imaging facilities for service provision and experimental help, Fabiola Vacca for supporting experiments, Neesha Kara for figure preparation, Matthew Sale, Andrew Kidger, Kathy Balmanno and Fatima Santos for experimental assistance and useful discussions.

\section{Funding}

PC and JH were funded by the Wellcome Trust [110216] and the BBSRC [BI Epigenetics ISP: BBS/E/B/000C0423]. SJC was funded by the BBSRC (BBS/E/B/000C0433) and CRUK (14867). PDS is a paid employee and shareholder of AstraZeneca plc. The funders had no role in study design, data collection and analysis, decision to publish, or preparation of the manuscript.

This research was funded in whole, or in part, by the Wellcome Trust [110216]. For the purpose of open access, the author has applied a CC BY public copyright licence to any Author Accepted Manuscript version arising from this submission.

\section{Conflict of interest statement}

PDS is a paid employee and shareholder of AstraZeneca plc. The remaining authors declare no conflicts of interest. 
bioRxiv preprint doi: https://doi.org/10.1101/2021.03.23.436572; this version posted March 23,2021 . The copyright holder for this preprint (which was not certified by peer review) is the author/funder, who has granted bioRxiv a license to display the preprint in perpetuity. It is made available under aCC-BY 4.0 International license.

Acquisition of MEKi resistance during DNA replication in drug

Channathodiyil et al.

\section{References}

1. L. A. Garraway, P. A. Janne, Circumventing cancer drug resistance in the era of personalized medicine. Cancer Discov 2, 214-226 (2012).

2. N. Vasan, J. Baselga, D. M. Hyman, A view on drug resistance in cancer. Nature 575, 299-309 (2019).

3. C. M. Lovly, A. T. Shaw, Molecular pathways: resistance to kinase inhibitors and implications for therapeutic strategies. Clin Cancer Res 20, 2249-2256 (2014).

4. A. A. Samatar, P. I. Poulikakos, Targeting RAS-ERK signalling in cancer: promises and challenges. Nat Rev Drug Discov 13, 928-942 (2014).

5. M. N. Balak, Y. Gong, G. J. Riely, R. Somwar, A. R. Li, M. F. Zakowski, A. Chiang, G. Yang, O. Ouerfelli, M. G. Kris, M. Ladanyi, V. A. Miller, W. Pao, Novel D761Y and common secondary T790M mutations in epidermal growth factor receptor-mutant lung adenocarcinomas with acquired resistance to kinase inhibitors. Clin Cancer Res 12, 6494-6501 (2006).

6. J. A. Engelman, K. Zejnullahu, T. Mitsudomi, Y. Song, C. Hyland, J. O. Park, N. Lindeman, C. M. Gale, X. Zhao, J. Christensen, T. Kosaka, A. J. Holmes, A. M. Rogers, F. Cappuzzo, T. Mok, C. Lee, B. E. Johnson, L. C. Cantley, P. A. Janne, MET amplification leads to gefitinib resistance in lung cancer by activating ERBB3 signaling. Science 316, 1039-1043 (2007).

7. T. Kosaka, Y. Yatabe, H. Endoh, K. Yoshida, T. Hida, M. Tsuboi, H. Tada, H. Kuwano, T. Mitsudomi, Analysis of epidermal growth factor receptor gene mutation in patients with nonsmall cell lung cancer and acquired resistance to gefitinib. Clin Cancer Res 12, 5764-5769 (2006).

8. H. Davies, G. R. Bignell, C. Cox, P. Stephens, S. Edkins, S. Clegg, J. Teague, H. Woffendin, M. J. Garnett, W. Bottomley, N. Davis, E. Dicks, R. Ewing, Y. Floyd, K. Gray, S. Hall, R. Hawes, J. Hughes, V. Kosmidou, A. Menzies, C. Mould, A. Parker, C. Stevens, S. Watt, S. Hooper, R. Wilson, H. Jayatilake, B. A. Gusterson, C. Cooper, J. Shipley, D. Hargrave, K. Pritchard-Jones, N. Maitland, G. Chenevix-Trench, G. J. Riggins, D. D. Bigner, G. Palmieri, A. Cossu, A. Flanagan, A. Nicholson, J. W. Ho, S. Y. Leung, S. T. Yuen, B. L. Weber, H. F. Seigler, T. L. Darrow, H. Paterson, R. Marais, C. J. Marshall, R. Wooster, M. R. Stratton, P. A. Futreal, Mutations of the BRAF gene in human cancer. Nature 417, 949-954 (2002).

9. R. Yaeger, R. B. Corcoran, Targeting Alterations in the RAF-MEK Pathway. Cancer Discov 9, 329341 (2019).

10. C. J. Caunt, M. J. Sale, P. D. Smith, S. J. Cook, MEK1 and MEK2 inhibitors and cancer therapy: the long and winding road. Nat Rev Cancer 15, 577-592 (2015).

11. M. Holderfield, M. M. Deuker, F. McCormick, M. McMahon, Targeting RAF kinases for cancer therapy: BRAF-mutated melanoma and beyond. Nat Rev Cancer 14, 455-467 (2014).

12. K. K. Ciombor, T. Bekaii-Saab, Selumetinib for the treatment of cancer. Expert Opin Investig Drugs 24, 111-123 (2015).

13. B. R. Davies, A. Logie, J. S. McKay, P. Martin, S. Steele, R. Jenkins, M. Cockerill, S. Cartlidge, P. D. Smith, AZD6244 (ARRY-142886), a potent inhibitor of mitogen-activated protein kinase/extracellular signal-regulated kinase kinase 1/2 kinases: mechanism of action in vivo, pharmacokinetic/pharmacodynamic relationship, and potential for combination in preclinical models. Mol Cancer Ther 6, 2209-2219 (2007).

14. T. C. Yeh, V. Marsh, B. A. Bernat, J. Ballard, H. Colwell, R. J. Evans, J. Parry, D. Smith, B. J. Brandhuber, S. Gross, A. Marlow, B. Hurley, J. Lyssikatos, P. A. Lee, J. D. Winkler, K. Koch, E. Wallace, Biological characterization of ARRY-142886 (AZD6244), a potent, highly selective mitogen-activated protein kinase kinase $1 / 2$ inhibitor. Clin Cancer Res 13, 1576-1583 (2007).

15. R. B. Corcoran, D. Dias-Santagata, K. Bergethon, A. J. lafrate, J. Settleman, J. A. Engelman, BRAF gene amplification can promote acquired resistance to MEK inhibitors in cancer cells harboring the BRAF V600E mutation. Sci Signal 3, ra84 (2010). 
bioRxiv preprint doi: https://doi.org/10.1101/2021.03.23.436572; this version posted March 23,2021 . The copyright holder for this preprint (which was not certified by peer review) is the author/funder, who has granted bioRxiv a license to display the preprint in perpetuity. It is made available under aCC-BY 4.0 International license.

16. A. S. Little, K. Balmanno, M. J. Sale, S. Newman, J. R. Dry, M. Hampson, P. A. Edwards, P. D. Smith, S. J. Cook, Amplification of the driving oncogene, KRAS or BRAF, underpins acquired resistance to MEK1/2 inhibitors in colorectal cancer cells. Sci Signal 4, ra17 (2011).

17. G. V. Long, C. Fung, A. M. Menzies, G. M. Pupo, M. S. Carlino, J. Hyman, H. Shahheydari, V. Tembe, J. F. Thompson, R. P. Saw, J. Howle, N. K. Hayward, P. Johansson, R. A. Scolyer, R. F. Kefford, H. Rizos, Increased MAPK reactivation in early resistance to dabrafenib/trametinib combination therapy of BRAF-mutant metastatic melanoma. Nat Commun 5, 5694 (2014).

18. D. Oddo, E. M. Sennott, L. Barault, E. Valtorta, S. Arena, A. Cassingena, G. Filiciotto, G. Marzolla, E. Elez, R. M. van Geel, A. Bartolini, G. Crisafulli, V. Boscaro, J. T. Godfrey, M. Buscarino, C. Cancelliere, M. Linnebacher, G. Corti, M. Truini, G. Siravegna, J. Grasselli, M. Gallicchio, R. Bernards, J. H. Schellens, J. Tabernero, J. A. Engelman, A. Sartore-Bianchi, A. Bardelli, S. Siena, R. B. Corcoran, F. Di Nicolantonio, Molecular Landscape of Acquired Resistance to Targeted Therapy Combinations in BRAF-Mutant Colorectal Cancer. Cancer Res 76, 4504-4515 (2016).

19. H. Shi, G. Moriceau, X. Kong, M. K. Lee, H. Lee, R. C. Koya, C. Ng, T. Chodon, R. A. Scolyer, K. B. Dahlman, J. A. Sosman, R. F. Kefford, G. V. Long, S. F. Nelson, A. Ribas, R. S. Lo, Melanoma whole-exome sequencing identifies (V600E)B-RAF amplification-mediated acquired B-RAF inhibitor resistance. Nat Commun 3, 724 (2012).

20. C. M. Emery, K. G. Vijayendran, M. C. Zipser, A. M. Sawyer, L. Niu, J. J. Kim, C. Hatton, R. Chopra, P. A. Oberholzer, M. B. Karpova, L. E. MacConaill, J. Zhang, N. S. Gray, W. R. Sellers, R. Dummer, L. A. Garraway, MEK1 mutations confer resistance to MEK and B-RAF inhibition. Proc Natl Acad Sci U S A 106, 20411-20416 (2009).

21. H. E. Bhang, D. A. Ruddy, V. Krishnamurthy Radhakrishna, J. X. Caushi, R. Zhao, M. M. Hims, A. P. Singh, I. Kao, D. Rakiec, P. Shaw, M. Balak, A. Raza, E. Ackley, N. Keen, M. R. Schlabach, M. Palmer, R. J. Leary, D. Y. Chiang, W. R. Sellers, F. Michor, V. G. Cooke, J. M. Korn, F. Stegmeier, Studying clonal dynamics in response to cancer therapy using high-complexity barcoding. Nat Med 21, 440-448 (2015).

22. L. A. Diaz, Jr., R. T. Williams, J. Wu, I. Kinde, J. R. Hecht, J. Berlin, B. Allen, I. Bozic, J. G. Reiter, M. A. Nowak, K. W. Kinzler, K. S. Oliner, B. Vogelstein, The molecular evolution of acquired resistance to targeted EGFR blockade in colorectal cancers. Nature 486, 537-540 (2012).

23. A. N. Hata, M. J. Niederst, H. L. Archibald, M. Gomez-Caraballo, F. M. Siddiqui, H. E. Mulvey, Y. E. Maruvka, F. Ji, H. E. Bhang, V. Krishnamurthy Radhakrishna, G. Siravegna, H. Hu, S. Raoof, E. Lockerman, A. Kalsy, D. Lee, C. L. Keating, D. A. Ruddy, L. J. Damon, A. S. Crystal, C. Costa, Z. Piotrowska, A. Bardelli, A. J. lafrate, R. I. Sadreyev, F. Stegmeier, G. Getz, L. V. Sequist, A. C. Faber, J. A. Engelman, Tumor cells can follow distinct evolutionary paths to become resistant to epidermal growth factor receptor inhibition. Nat Med 22, 262-269 (2016).

24. G. V. Echeverria, Z. Ge, S. Seth, X. Zhang, S. Jeter-Jones, X. Zhou, S. Cai, Y. Tu, A. McCoy, M. Peoples, Y. Sun, H. Qiu, Q. Chang, C. Bristow, A. Carugo, J. Shao, X. Ma, A. Harris, P. Mundi, R. Lau, V. Ramamoorthy, Y. Wu, M. J. Alvarez, A. Califano, S. L. Moulder, W. F. Symmans, J. R. Marszalek, T. P. Heffernan, J. T. Chang, H. Piwnica-Worms, Resistance to neoadjuvant chemotherapy in triple-negative breast cancer mediated by a reversible drug-tolerant state. Sci Transl Med 11, (2019).

25. D. Ravindran Menon, S. Das, C. Krepler, A. Vultur, B. Rinner, S. Schauer, K. Kashofer, K. Wagner, G. Zhang, E. Bonyadi Rad, N. K. Haass, H. P. Soyer, B. Gabrielli, R. Somasundaram, G. Hoefler, $M$. Herlyn, H. Schaider, A stress-induced early innate response causes multidrug tolerance in melanoma. Oncogene 34, 4448-4459 (2015).

26. S. K. Rehman, J. Haynes, E. Collignon, K. R. Brown, Y. Wang, A. M. L. Nixon, J. P. Bruce, J. A. Wintersinger, A. Singh Mer, E. B. L. Lo, C. Leung, E. Lima-Fernandes, N. M. Pedley, F. Soares, S. McGibbon, H. H. He, A. Pollet, T. J. Pugh, B. Haibe-Kains, Q. Morris, M. Ramalho-Santos, S. Goyal, J. Moffat, C. A. O'Brien, Colorectal Cancer Cells Enter a Diapause-like DTP State to Survive Chemotherapy. Cell 184, 226-242 e221 (2021). 
bioRxiv preprint doi: https://doi.org/10.1101/2021.03.23.436572; this version posted March 23,2021 . The copyright holder for this preprint (which was not certified by peer review) is the author/funder, who has granted bioRxiv a license to display the preprint in perpetuity. It is made available under aCC-BY 4.0 International license.

27. S. V. Sharma, D. Y. Lee, B. Li, M. P. Quinlan, F. Takahashi, S. Maheswaran, U. McDermott, N. Azizian, L. Zou, M. A. Fischbach, K. K. Wong, K. Brandstetter, B. Wittner, S. Ramaswamy, M. Classon, J. Settleman, A chromatin-mediated reversible drug-tolerant state in cancer cell subpopulations. Cell 141, 69-80 (2010).

28. G. D. Guler, C. A. Tindell, R. Pitti, C. Wilson, K. Nichols, T. KaiWai Cheung, H. J. Kim, M. Wongchenko, Y. Yan, B. Haley, T. Cuellar, J. Webster, N. Alag, G. Hegde, E. Jackson, T. L. Nance, P. G. Giresi, K. B. Chen, J. Liu, S. Jhunjhunwala, J. Settleman, J. P. Stephan, D. Arnott, M. Classon, Repression of Stress-Induced LINE-1 Expression Protects Cancer Cell Subpopulations from Lethal Drug Exposure. Cancer Cell 32, 221-237 e213 (2017).

29. M. J. Hangauer, V. S. Viswanathan, M. J. Ryan, D. Bole, J. K. Eaton, A. Matov, J. Galeas, H. D. Dhruv, M. E. Berens, S. L. Schreiber, F. McCormick, M. T. McManus, Drug-tolerant persister cancer cells are vulnerable to GPX4 inhibition. Nature 551, 247-250 (2017).

30. B. B. Liau, C. Sievers, L. K. Donohue, S. M. Gillespie, W. A. Flavahan, T. E. Miller, A. S. Venteicher, C. H. Hebert, C. D. Carey, S. J. Rodig, S. J. Shareef, F. J. Najm, P. van Galen, H. Wakimoto, D. P. Cahill, J. N. Rich, J. C. Aster, M. L. Suva, A. P. Patel, B. E. Bernstein, Adaptive Chromatin Remodeling Drives Glioblastoma Stem Cell Plasticity and Drug Tolerance. Cell Stem Cell 20, 233-246 e237 (2017).

31. Y. Oren, M. Tsabar, H. F. Cabanos, M. S. Cuoco, E. Zaganjor, P. I. Thakore, M. Tabaka, C. P. Fulco, S. A. Hurvitz, D. J. Slamon, G. Lahav, A. Hata, J. S. Brugge, A. Regev, Cycling cancer persister cells arise from lineages with distinct transcriptional and metabolic programs. bioRxiv, 2020.2006.2005.136358 (2020).

32. M. Ramirez, S. Rajaram, R. J. Steininger, D. Osipchuk, M. A. Roth, L. S. Morinishi, L. Evans, W. Ji, C. H. Hsu, K. Thurley, S. Wei, A. Zhou, P. R. Koduru, B. A. Posner, L. F. Wu, S. J. Altschuler, Diverse drug-resistance mechanisms can emerge from drug-tolerant cancer persister cells. Nat Commun 7, 10690 (2016).

33. A. Cipponi, D. L. Goode, J. Bedo, M. J. McCabe, M. Pajic, D. R. Croucher, A. G. Rajal, S. R. Junankar, D. N. Saunders, P. Lobachevsky, A. T. Papenfuss, D. Nessem, M. Nobis, S. C. Warren, P. Timpson, M. Cowley, A. C. Vargas, M. R. Qiu, D. G. Generali, S. Keerthikumar, U. Nguyen, N. M. Corcoran, G. V. Long, J. Y. Blay, D. M. Thomas, MTOR signaling orchestrates stress-induced mutagenesis, facilitating adaptive evolution in cancer. Science 368, 1127-1131 (2020).

34. D. M. Fitzgerald, P. J. Hastings, S. M. Rosenberg, Stress-Induced Mutagenesis: Implications in Cancer and Drug Resistance. Annu Rev Cancer Biol 1, 119-140 (2017).

35. M. Russo, G. Crisafulli, A. Sogari, N. M. Reilly, S. Arena, S. Lamba, A. Bartolini, V. Amodio, A. Magri, L. Novara, I. Sarotto, Z. D. Nagel, C. G. Piett, A. Amatu, A. Sartore-Bianchi, S. Siena, A. Bertotti, L. Trusolino, M. Corigliano, M. Gherardi, M. C. Lagomarsino, F. Di Nicolantonio, A. Bardelli, Adaptive mutability of colorectal cancers in response to targeted therapies. Science 366, 1473-1480 (2019).

36. M. Min, S. L. Spencer, Spontaneously slow-cycling subpopulations of human cells originate from activation of stress-response pathways. PLoS Biol 17, e3000178 (2019).

37. K. Temprine, N. R. Campbell, R. Huang, E. M. Langdon, T. Simon-Vermot, K. Mehta, A. Clapp, M. Chipman, R. M. White, Regulation of the error-prone DNA polymerase Polkappa by oncogenic signaling and its contribution to drug resistance. Sci Signal 13, (2020).

38. M. J. Sale, K. Balmanno, J. Saxena, E. Ozono, K. Wojdyla, R. E. McIntyre, R. Gilley, A. Woroniuk, K. D. Howarth, G. Hughes, J. R. Dry, M. J. Arends, P. Caro, D. Oxley, S. Ashton, D. J. Adams, J. Saez-Rodriguez, P. D. Smith, S. J. Cook, MEK1/2 inhibitor withdrawal reverses acquired resistance driven by BRAF(V600E) amplification whereas KRAS(G13D) amplification promotes EMT-chemoresistance. Nat Commun 10, 2030 (2019).

39. M. Cheng, V. Sexl, C. J. Sherr, M. F. Roussel, Assembly of cyclin D-dependent kinase and titration of p27Kip1 regulated by mitogen-activated protein kinase kinase (MEK1). Proc Nat/ Acad Sci U S A 95, 1091-1096 (1998). 
bioRxiv preprint doi: https://doi.org/10.1101/2021.03.23.436572; this version posted March 23,2021 . The copyright holder for this preprint (which was not certified by peer review) is the author/funder, who has granted bioRxiv a license to display the preprint in perpetuity. It is made available under aCC-BY 4.0 International license.

40. D. B. Solit, L. A. Garraway, C. A. Pratilas, A. Sawai, G. Getz, A. Basso, Q. Ye, J. M. Lobo, Y. She, I. Osman, T. R. Golub, J. Sebolt-Leopold, W. R. Sellers, N. Rosen, BRAF mutation predicts sensitivity to MEK inhibition. Nature 439, 358-362 (2006).

41. C. Bailey, M. J. Shoura, P. S. Mischel, C. Swanton, Extrachromosomal DNA-relieving heredity constraints, accelerating tumour evolution. Ann Oncol 31, 884-893 (2020).

42. P. J. Hastings, J. R. Lupski, S. M. Rosenberg, G. Ira, Mechanisms of change in gene copy number. Nat Rev Genet 10, 551-564 (2009).

43. L. Gerosa, C. Chidley, F. Frohlich, G. Sanchez, S. K. Lim, J. Muhlich, J. Y. Chen, S. Vallabhaneni, G. J. Baker, D. Schapiro, M. I. Atanasova, L. A. Chylek, T. Shi, L. Yi, C. D. Nicora, A. Claas, T. S. C. Ng, R. H. Kohler, D. A. Lauffenburger, R. Weissleder, M. A. Miller, W. J. Qian, H. S. Wiley, P. K. Sorger, Receptor-Driven ERK Pulses Reconfigure MAPK Signaling and Enable Persistence of Drug-Adapted BRAF-Mutant Melanoma Cells. Cell Syst 11, 478-494 e479 (2020).

44. J. C. Chambard, R. Lefloch, J. Pouyssegur, P. Lenormand, ERK implication in cell cycle regulation. Biochim Biophys Acta 1773, 1299-1310 (2007).

45. O. Maertens, R. Kuzmickas, H. E. Manchester, C. E. Emerson, A. G. Gavin, C. J. Guild, T. C. Wong, T. De Raedt, C. Bowman-Colin, E. Hatchi, L. A. Garraway, K. T. Flaherty, S. Pathania, S. J. Elledge, K. Cichowski, MAPK Pathway Suppression Unmasks Latent DNA Repair Defects and Confers a Chemical Synthetic Vulnerability in BRAF-, NRAS-, and NF1-Mutant Melanomas. Cancer Discov 9, 526-545 (2019).

46. F. Vena, R. Jia, A. Esfandiari, J. J. Garcia-Gomez, M. Rodriguez-Justo, J. Ma, S. Syed, L. Crowley, B. Elenbaas, S. Goodstal, J. A. Hartley, D. Hochhauser, MEK inhibition leads to BRCA2 downregulation and sensitization to DNA damaging agents in pancreas and ovarian cancer models. Oncotarget 9, 11592-11603 (2018).

47. C. A. Pratilas, B. S. Taylor, Q. Ye, A. Viale, C. Sander, D. B. Solit, N. Rosen, (V600E)BRAF is associated with disabled feedback inhibition of RAF-MEK signaling and elevated transcriptional output of the pathway. Proc Natl Acad Sci U S A 106, 4519-4524 (2009).

48. P. Channathodiyil, J. Houseley, Glyoxal fixation facilitates transcriptome analysis after antigen staining and cell sorting by flow cytometry. PLoS One 16, e0240769 (2021).

49. J. R. Dry, S. Pavey, C. A. Pratilas, C. Harbron, S. Runswick, D. Hodgson, C. Chresta, R. McCormack, N. Byrne, M. Cockerill, A. Graham, G. Beran, A. Cassidy, C. Haggerty, H. Brown, G. Ellison, J. Dering, B. S. Taylor, M. Stark, V. Bonazzi, S. Ravishankar, L. Packer, F. Xing, D. B. Solit, R. S. Finn, N. Rosen, N. K. Hayward, T. French, P. D. Smith, Transcriptional pathway signatures predict MEK addiction and response to selumetinib (AZD6244). Cancer Res 70, 2264-2273 (2010).

50. S. Ishida, E. Huang, H. Zuzan, R. Spang, G. Leone, M. West, J. R. Nevins, Role for E2F in control of both DNA replication and mitotic functions as revealed from DNA microarray analysis. Mol Cell Biol 21, 4684-4699 (2001).

51. R. Iwanaga, H. Komori, S. Ishida, N. Okamura, K. Nakayama, K. I. Nakayama, K. Ohtani, Identification of novel E2F1 target genes regulated in cell cycle-dependent and independent manners. Oncogene 25, 1786-1798 (2006).

52. K. Ohtani, R. Iwanaga, M. Nakamura, M. Ikeda, N. Yabuta, H. Tsuruga, H. Nojima, Cell growthregulated expression of mammalian MCM5 and MCM6 genes mediated by the transcription factor E2F. Oncogene 18, 2299-2309 (1999).

53. E. L. Baple, H. Chambers, H. E. Cross, H. Fawcett, Y. Nakazawa, B. A. Chioza, G. V. Harlalka, S. Mansour, A. Sreekantan-Nair, M. A. Patton, M. Muggenthaler, P. Rich, K. Wagner, R. Coblentz, C. K. Stein, J. I. Last, A. M. Taylor, A. P. Jackson, T. Ogi, A. R. Lehmann, C. M. Green, A. H. Crosby, Hypomorphic PCNA mutation underlies a human DNA repair disorder. J Clin Invest 124, 31373146 (2014).

54. D. M. Chou, S. J. Elledge, Tipin and Timeless form a mutually protective complex required for genotoxic stress resistance and checkpoint function. Proc Natl Acad Sci U S A 103, 1814318147 (2006). 
bioRxiv preprint doi: https://doi.org/10.1101/2021.03.23.436572; this version posted March 23,2021 . The copyright holder for this preprint (which was not certified by peer review) is the author/funder, who has granted bioRxiv a license to display the preprint in perpetuity. It is made available under aCC-BY 4.0 International license.

55. S. C. Pruitt, K. J. Bailey, A. Freeland, Reduced Mcm2 expression results in severe stem/progenitor cell deficiency and cancer. Stem Cells 25, 3121-3132 (2007).

56. N. Shima, A. Alcaraz, I. Liachko, T. R. Buske, C. A. Andrews, R. J. Munroe, S. A. Hartford, B. K. Tye, J. C. Schimenti, A viable allele of $\mathrm{Mcm} 4$ causes chromosome instability and mammary adenocarcinomas in mice. Nat Genet 39, 93-98 (2007).

57. L. Zheng, H. Dai, M. Zhou, M. Li, P. Singh, J. Qiu, W. Tsark, Q. Huang, K. Kernstine, X. Zhang, D. Lin, B. Shen, Fen1 mutations result in autoimmunity, chronic inflammation and cancers. Nat Med 13, 812-819 (2007).

58. R. Bravo, H. Macdonald-Bravo, Existence of two populations of cyclin/proliferating cell nuclear antigen during the cell cycle: association with DNA replication sites. J Cell Biol 105, 1549-1554 (1987).

59. T. Guida, G. Salvatore, P. Faviana, R. Giannini, G. Garcia-Rostan, L. Provitera, F. Basolo, A. Fusco, F. Carlomagno, M. Santoro, Mitogenic effects of the up-regulation of minichromosome maintenance proteins in anaplastic thyroid carcinoma. J Clin Endocrinol Metab 90, 4703-4709 (2005).

60. V. Santosa, M. T. Kanemaki, MCMBP maintains genome integrity by protecting the MCM subunits from degradation. bioRxiv, 827386 (2019).

61. C. H. Chuang, M. D. Wallace, C. Abratte, T. Southard, J. C. Schimenti, Incremental genetic perturbations to MCM2-7 expression and subcellular distribution reveal exquisite sensitivity of mice to DNA replication stress. PLoS Genet 6, e1001110 (2010).

62. X. Q. Ge, D. A. Jackson, J. J. Blow, Dormant origins licensed by excess Mcm2-7 are required for human cells to survive replicative stress. Genes Dev 21, 3331-3341 (2007).

63. C. Bertoli, J. M. Skotheim, R. A. de Bruin, Control of cell cycle transcription during $\mathrm{G} 1$ and S phases. Nat Rev Mol Cell Biol 14, 518-528 (2013).

64. A. S. Lundberg, R. A. Weinberg, Functional inactivation of the retinoblastoma protein requires sequential modification by at least two distinct cyclin-cdk complexes. Mol Cell Biol 18, 753761 (1998).

65. L. N. Kwong, J. C. Costello, H. Liu, S. Jiang, T. L. Helms, A. E. Langsdorf, D. Jakubosky, G. Genovese, F. L. Muller, J. H. Jeong, R. P. Bender, G. C. Chu, K. T. Flaherty, J. A. Wargo, J. J. Collins, L. Chin, Oncogenic NRAS signaling differentially regulates survival and proliferation in melanoma. Nat Med 18, 1503-1510 (2012).

66. J. A. Sosman, M. Kittaneh, M. P. J. K. Lolkema, M. A. Postow, G. Schwartz, C. Franklin, A. Matano, S. Bhansali, S. Parasuraman, K. Kim, A phase 1b/2 study of LEE011 in combination with binimetinib (MEK162) in patients with NRAS-mutant melanoma: Early encouraging clinical activity. Journal of Clinical Oncology 32, 9009-9009 (2014).

67. Y. Liu, A. Beyer, R. Aebersold, On the Dependency of Cellular Protein Levels on mRNA Abundance. Cell 165, 535-550 (2016).

68. D. S. Dimitrova, T. A. Prokhorova, J. J. Blow, I. T. Todorov, D. M. Gilbert, Mammalian nuclei become licensed for DNA replication during late telophase. J Cell Sci 115, 51-59 (2002).

69. M. A. Kuipers, T. J. Stasevich, T. Sasaki, K. A. Wilson, K. L. Hazelwood, J. G. McNally, M. W. Davidson, D. M. Gilbert, Highly stable loading of $\mathrm{Mcm}$ proteins onto chromatin in living cells requires replication to unload. J Cell Biol 192, 29-41 (2011).

70. G. Chen, W. D. Bradford, C. W. Seidel, R. Li, Hsp90 stress potentiates rapid cellular adaptation through induction of aneuploidy. Nature 482, 246-250 (2012).

71. B. D. Harrison, J. Hashemi, M. Bibi, R. Pulver, D. Bavli, Y. Nahmias, M. Wellington, G. Sapiro, J. Berman, A tetraploid intermediate precedes aneuploid formation in yeasts exposed to fluconazole. PLoS Biol 12, e1001815 (2014).

72. S. M. Rosenberg, C. Shee, R. L. Frisch, P. J. Hastings, Stress-induced mutation via DNA breaks in Escherichia coli: a molecular mechanism with implications for evolution and medicine. Bioessays 34, 885-892 (2012). 
bioRxiv preprint doi: $\mathrm{https}$ ://doi.org/10.1101/2021.03.23.436572; this version posted March 23, 2021. The copyright holder for this preprint (which was not certified by peer review) is the author/funder, who has granted bioRxiv a license to display the preprint in perpetuity. It is made available under aCC-BY 4.0 International license.

73. E. Shor, C. A. Fox, J. R. Broach, The yeast environmental stress response regulates mutagenesis induced by proteotoxic stress. PLoS Genet 9, e1003680 (2013).

74. D. W. Fry, P. J. Harvey, P. R. Keller, W. L. Elliott, M. Meade, E. Trachet, M. Albassam, X. Zheng, W. R. Leopold, N. K. Pryer, P. L. Toogood, Specific inhibition of cyclin-dependent kinase 4/6 by PD 0332991 and associated antitumor activity in human tumor xenografts. Mol Cancer Ther 3, 1427-1438 (2004).

75. K. Z. Guiley, J. W. Stevenson, K. Lou, K. J. Barkovich, V. Kumarasamy, T. U. Wijeratne, K. L. Bunch, S. Tripathi, E. S. Knudsen, A. K. Witkiewicz, K. M. Shokat, S. M. Rubin, p27 allosterically activates cyclin-dependent kinase 4 and antagonizes palbociclib inhibition. Science 366, (2019).

76. N. P. Pavletich, Mechanisms of cyclin-dependent kinase regulation: structures of Cdks, their cyclin activators, and Cip and INK4 inhibitors. J Mol Biol 287, 821-828 (1999).

77. K. Polyak, M. H. Lee, H. Erdjument-Bromage, A. Koff, J. M. Roberts, P. Tempst, J. Massague, Cloning of p27Kip1, a cyclin-dependent kinase inhibitor and a potential mediator of extracellular antimitogenic signals. Cell 78, 59-66 (1994).

78. D. Kim, J. M. Paggi, C. Park, C. Bennett, S. L. Salzberg, Graph-based genome alignment and genotyping with HISAT2 and HISAT-genotype. Nat Biotechnol 37, 907-915 (2019).

79. M. I. Love, W. Huber, S. Anders, Moderated estimation of fold change and dispersion for RNAseq data with DESeq2. Genome Biol 15, 550 (2014).

80. E. Eden, D. Lipson, S. Yogev, Z. Yakhini, Discovering motifs in ranked lists of DNA sequences. PLoS Comput Biol 3, e39 (2007).

81. E. Eden, R. Navon, I. Steinfeld, D. Lipson, Z. Yakhini, GOrilla: a tool for discovery and visualization of enriched GO terms in ranked gene lists. BMC Bioinformatics 10, 48 (2009).

82. Y. Benjamini, Y. Hochberg, Controlling the False Discovery Rate: A Practical and Powerful Approach to Multiple Testing. Journal of the Royal Statistical Society: Series $B$ (Methodological) 57, 289-300 (1995). 
bioRxiv preprint doi: https://doi.org/10.1101/2021.03.23.436572; this version posted March 23, 2021. The copyright holder for this preprint (which was not certified by peer review) is the author/funder, who has granted bioRxiv a license to display the preprint in perpetuity. It is made available under aCC-BY 4.0 International license.

\section{Acquisition of MEKi resistance during DNA replication in drug \\ Channathodiyil et al.}

Figures

A

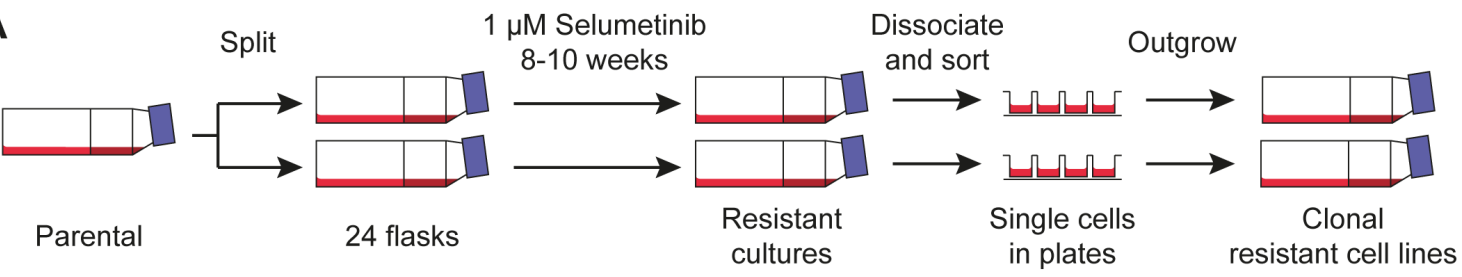

B

C

$B R A F$ copy number in parental and resistant clones
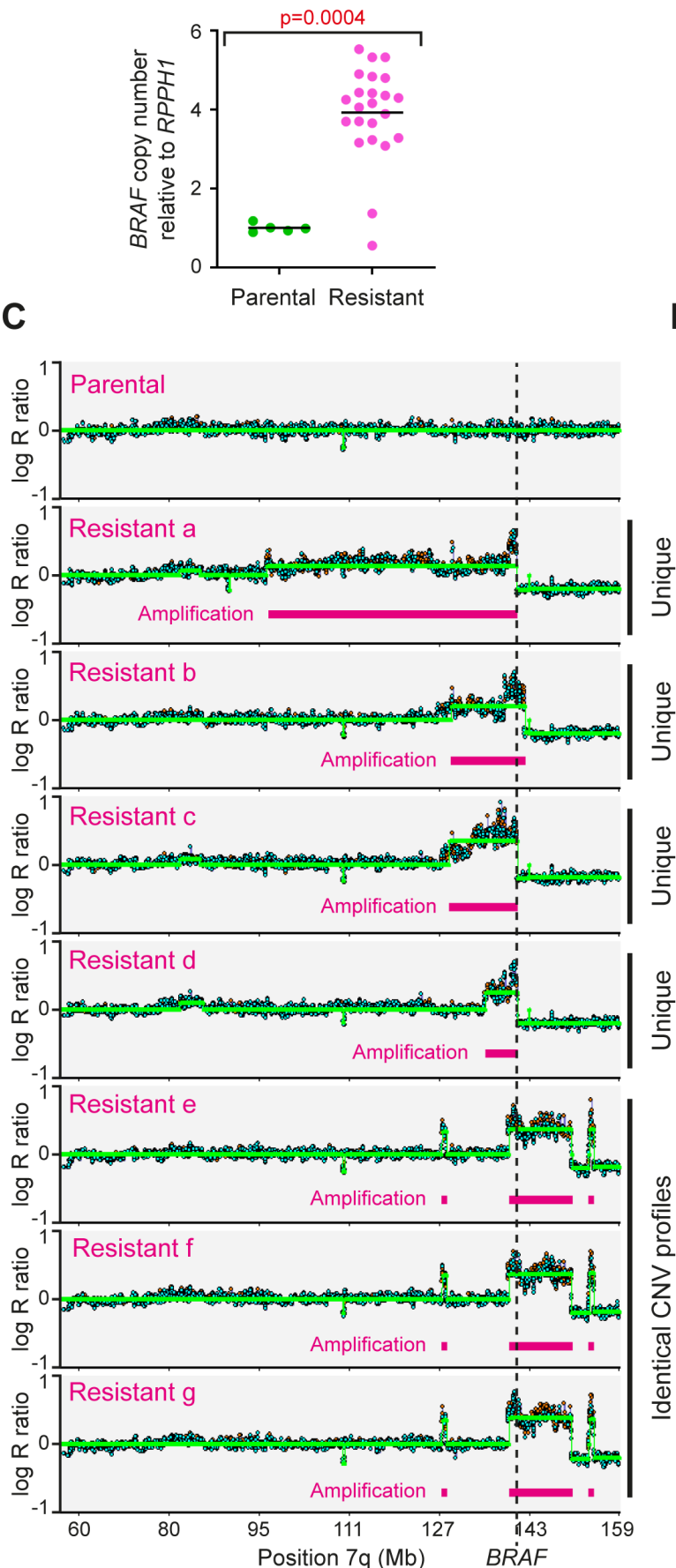

D

Time to acquire selumetinib resistance in clonal COLO205 derivatives

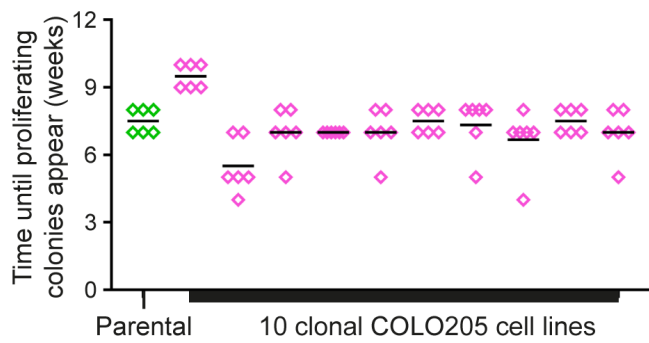

E
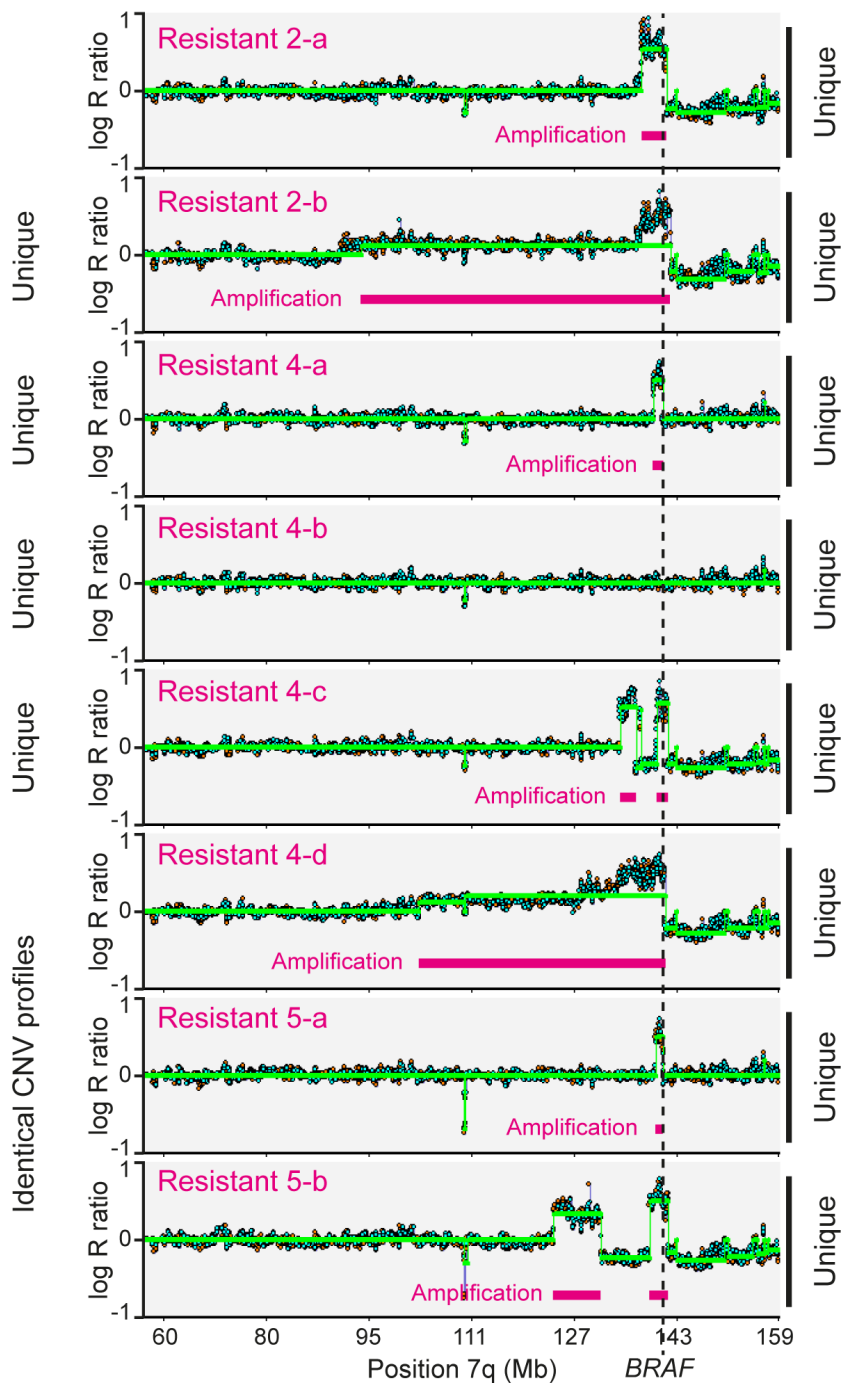
bioRxiv preprint doi: https://doi.org/10.1101/2021.03.23.436572; this version posted March 23, 2021. The copyright holder for this preprint (which was not certified by peer review) is the author/funder, who has granted bioRxiv a license to display the preprint in perpetuity. It is made available under aCC-BY 4.0 International license.

\section{Figure 1: Contributions of pre-existing and de novo gene amplifications to the emergence} of selumetinib resistance in COLO205 cells

A: Experimental design for analysing reproducibility of resistance. Proliferating COLO205 cells were seeded in 24 individual $25 \mathrm{~cm}^{2}$ cell culture flasks and $1 \mu \mathrm{M}$ selumetinib added after 24 hours. Media and drug were changed weekly until colonies of proliferating cells were observed, at which point single cells were isolated by flow cytometry and expanded into separate drug resistant cell lines in the presence of $1 \mu \mathrm{M}$ selumetinib. After addition of selumetinib, the cell density did not increase and cells were not split across the duration of the treatment.

B: qPCR copy number analysis of $B R A F$ relative to $R P P H 1$ in parental and selumetinib-resistant cell lines derived as in A. Data for 5 biological replicates of parental COLO205 cells and 23 independently-derived selumetinib resistant cells lines are shown; 21 of 23 selumetinib resistant cell lines show $>3$ fold amplification of BRAF relative RPPH1. Each assay was performed in triplicate. $p$ value was calculated by Mann-Whitney test ( $n=5$ parental, 23 resistant).

C: Copy number profiles of the BRAF locus in 7 selumetinib resistant cell lines compared to parental cells, determined using CytoSNP 850K BeadChip arrays (Illumina) and analysed with BlueFuse multi software version 4.5 based on the reference human genome (hg19/GRCh37). $\log _{2}$ ratio plots of copy number for the $q$ arm of chromosome 7 are shown, including the location of BRAF (dotted line) and amplified regions (pink bars). Each resistant cell line derived from clonal amplification of individual selumetinib resistant cells from independent drug treatment flasks, but note that cell lines $e, f$ and $g$ show identical and highly characteristic copy number amplification profiles.

D: Time taken for proliferating selumetinib resistant clones to emerge from parental and 10 different single cell derived COLO205 cell lines. For each cell line, cells were seeded in 6-well plates and treated individually with $1 \mu \mathrm{M}$ selumetinib after 24 hours. Media and drug were changed weekly, and the time taken until the first colony ( $\geq 50$ cells) of proliferating cells was observed in each well and recorded (in weeks). The time to resistance was not significantly different between the parental line and any of the clonal lines ( $p>0.5)$ by a Kruskal-Wallis test. $\mathrm{E}$ : CNV profiles of the BRAF locus in 8 selumetinib resistant lines obtained from clonal parental cell lines, each resistant cell line derived by clonal amplification from an independent drug treatment flask, analysed as in $\mathbf{C}$. Three clonal parental cell lines (clonal cell lines 2, 4 and 5) were used, with four resistant clones derived from cell line 4 and 2 each from cell lines 2 and 5. Note that all CNV profiles are different, and that cell line 4-b has become resistant without amplification of the BRAF locus or any region detectable by array-based CNV analysis. 
bioRxiv preprint doi: https://doi.org/10.1101/2021.03.23.436572; this version posted March 23, 2021. The copyright holder for this preprint (which was not certified by peer review) is the author/funder, who has granted bioRxiv a license to display the preprint in perpetuity. It is made available under aCC-BY 4.0 International license.

\section{Acquisition of MEKi resistance during DNA replication in drug Channathodiyil et al.}

A

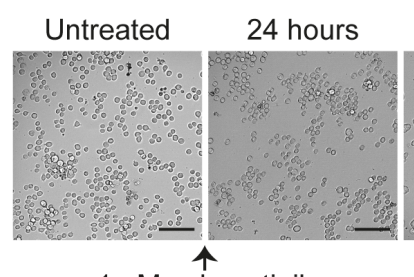

$1 \mu \mathrm{M}$ selumetinib addition

B

Untreated
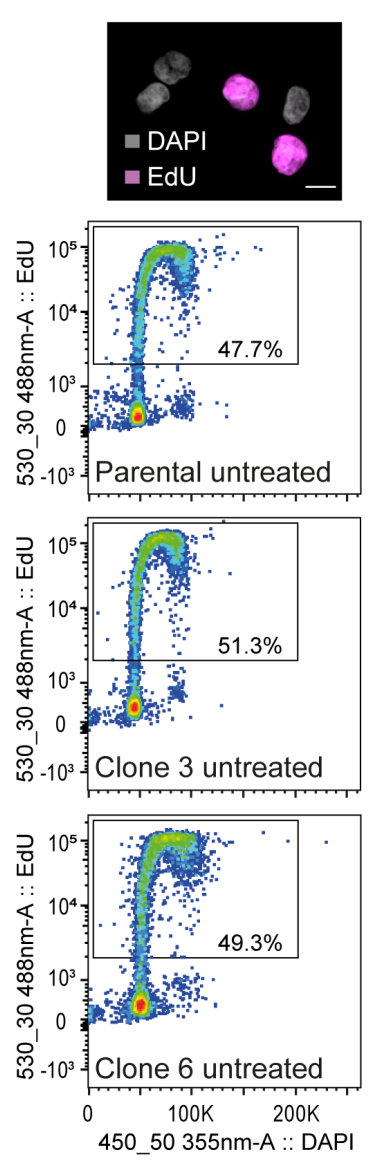

C

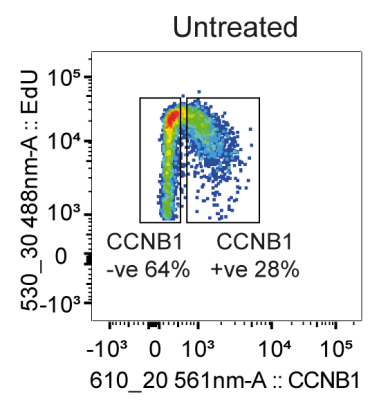

1 week

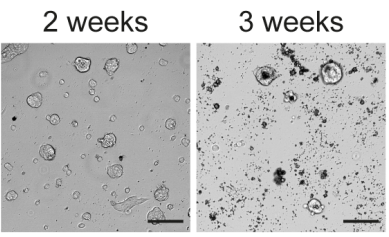

5 weeks
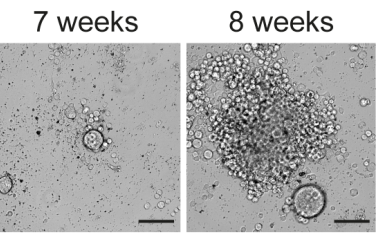

D

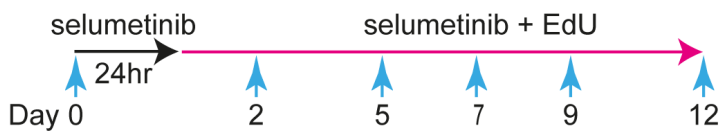

24 hours selumetinib 4 hours EdU + selumetinib
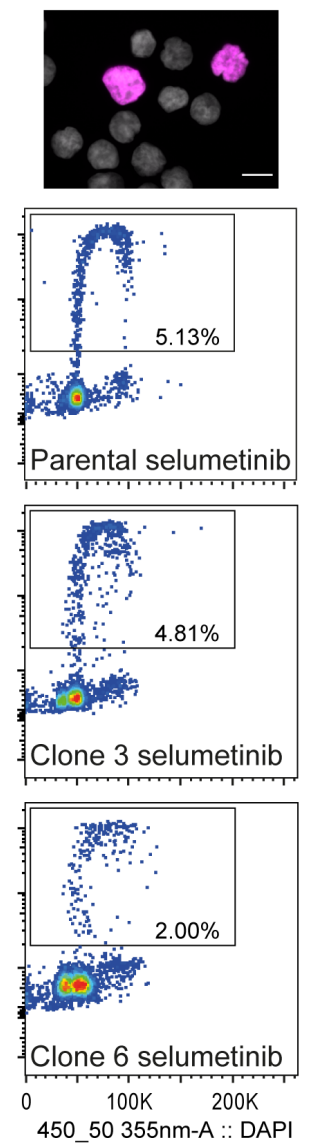

Selumetinib

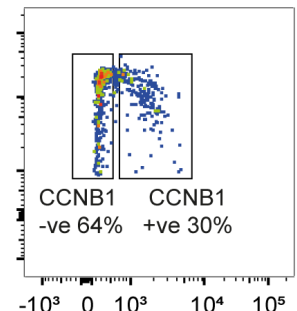

$61020561 \mathrm{~nm}-\mathrm{A} \cdot \cdot$
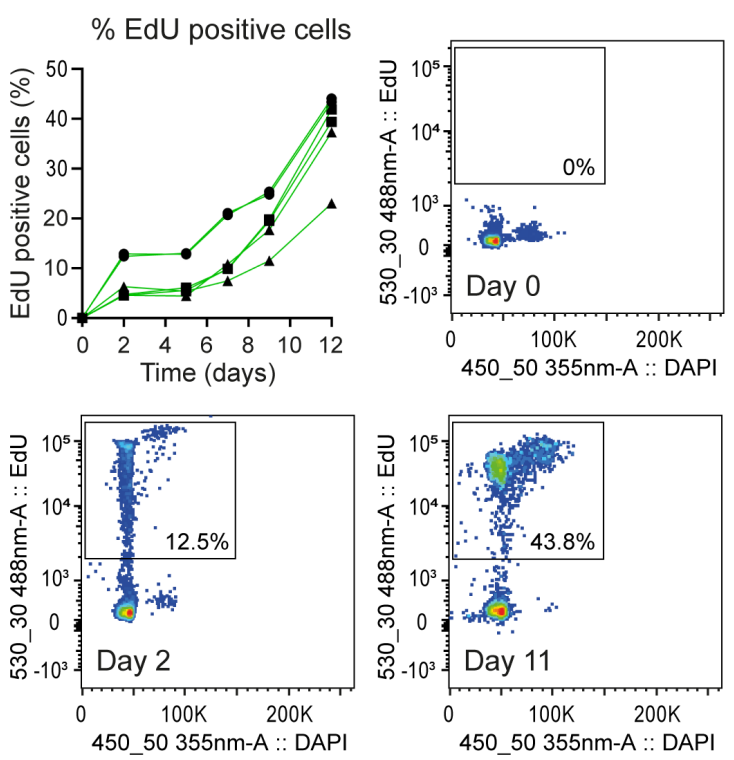

E
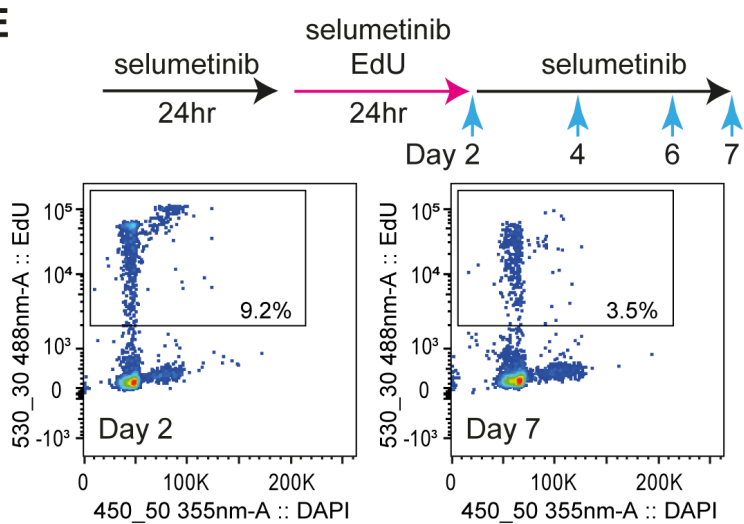

$\%$ EdU positive cells

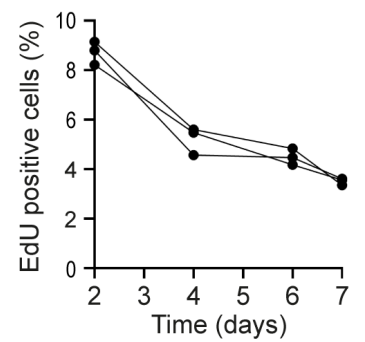

EdU intensity per cell

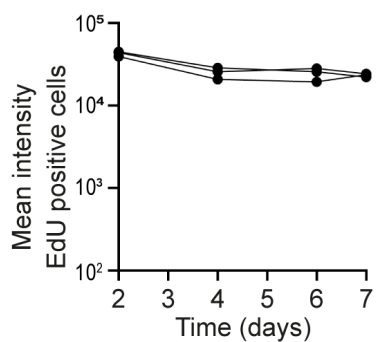


bioRxiv preprint doi: https://doi.org/10.1101/2021.03.23.436572; this version posted March 23, 2021. The copyright holder for this preprint (which was not certified by peer review) is the author/funder, who has granted bioRxiv a license to display the preprint in perpetuity. It is made available under aCC-BY 4.0 International license.

Figure 2: Replicating cells persist in long-term selumetinib-treated cell cultures

A: Representative brightfield images of COLO205 cells during extended treatment with $1 \mu \mathrm{M}$ selumetinib. Scale bars represent $100 \mu \mathrm{m}$.

B: EdU incorporation during selumetinib treatment. COLO205 cells were treated for 24 hours with $1 \mu \mathrm{M}$ selumetinib before addition of $10 \mu \mathrm{M}$ EdU for 4 hours. Representative images of EdU negative and positive cells (pink) co-stained with DAPI (grey) from selumetinib treated and control cells are shown at top, scale bars represent $10 \mu \mathrm{m}$. Quantification of EdU positive cells in each population by flow cytometry is shown below for parental COLO205 cells and single cell derived clones 3 and 6 . Individual plots show EdU incorporation versus DAPI staining of DNA for untreated (left) and selumetinib treated cells (right), with rectangles to indicate gates used to quantify EdU positive and negative cells. Percent EdU positive cells are shown within the gates for each sample.

C: Quantification by flow cytometry of CCNB1 negative and positive cells amongst the EdU positive cell population in untreated (left) and selumetinib treated (right) samples. COLO205 cells were treated with $1 \mu \mathrm{M}$ selumetinib or DMSO only for 24 hours before addition of 10 $\mu \mathrm{M}$ EdU for 4 hours in the presence or absence of $1 \mu \mathrm{M}$ selumetinib respectively. Cells were stained with EdU reaction cocktail and counter stained with CCNB1 primary antibody and Alexa Fluor 594 conjugated donkey anti-rabbit secondary antibody. Individual plots show EdU incorporation versus CCNB1 staining for untreated (left) and selumetinib treated (right), with rectangles to indicate gates used to quantify CCNB1 negative and positive cells in the EdU positive population. Percent CCNB1 positive and negative cells are shown within the gates for each sample.

D: Quantification of EdU positive cells by flow cytometry in COLO205 cells grown in the presence of selumetinib and EdU over the course of 11 days. COLO205 cells were treated for 24 hours with $1 \mu \mathrm{M}$ selumetinib before addition of $2 \mu \mathrm{M}$ EdU for 6 days, after which cells were rinsed with cell culture media then treated with $1 \mu \mathrm{M}$ selumetinib and $2 \mu \mathrm{M}$ EdU for a further 5 days. EdU incorporation was assayed at the indicated time points. Data for 6 independent replicates are shown.

E: EdU positive cells do not increase with prolonged selumetinib treatment. COLO205 cells were treated with $1 \mu \mathrm{M}$ selumetinib for 24 hours before addition of $2 \mu \mathrm{M}$ EdU for 24 hours in the presence of $1 \mu \mathrm{M}$ selumetinib, after which cells were rinsed in cell culture media and grown in the presence of $1 \mu \mathrm{M}$ selumetinib only for up to 5 days. EdU incorporation was assayed at the indicated time points by flow cytometry. Results are mean of 2 independent replicates. Quantitation of EdU positive cells (left) and EdU intensity per cell (right), $n=3$ are shown in the bottom panel. 
bioRxiv preprint doi: $h$ ttps://doi.org/10.1101/2021.03 23 436572; this version posted March 23, 2021. The copyright holder for this preprint (which was not certified by peer review) is the author/funder, who has granted bioRxiv a license to display the preprint in perpetuity. It is made available under aCC-BY 4.0 International license.

\section{Acquisition of MEKi resistance during DNA replication in drug}

Channathodiyil et al.

A

pERK v. EdU in selumetinib treated and control cells

Untreated

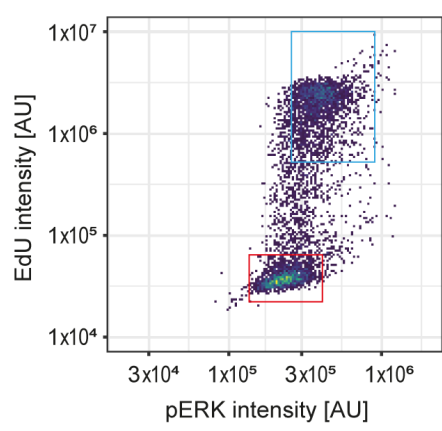

24 hours selumetinib

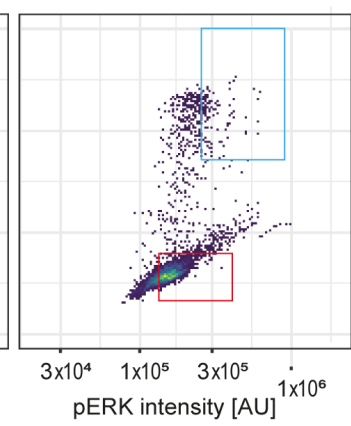

C

Genes $>4$-fold differentially expressed between CCNB1 -ve and +ve in untreated and 24 hour selumetinib-treated cells (1681)

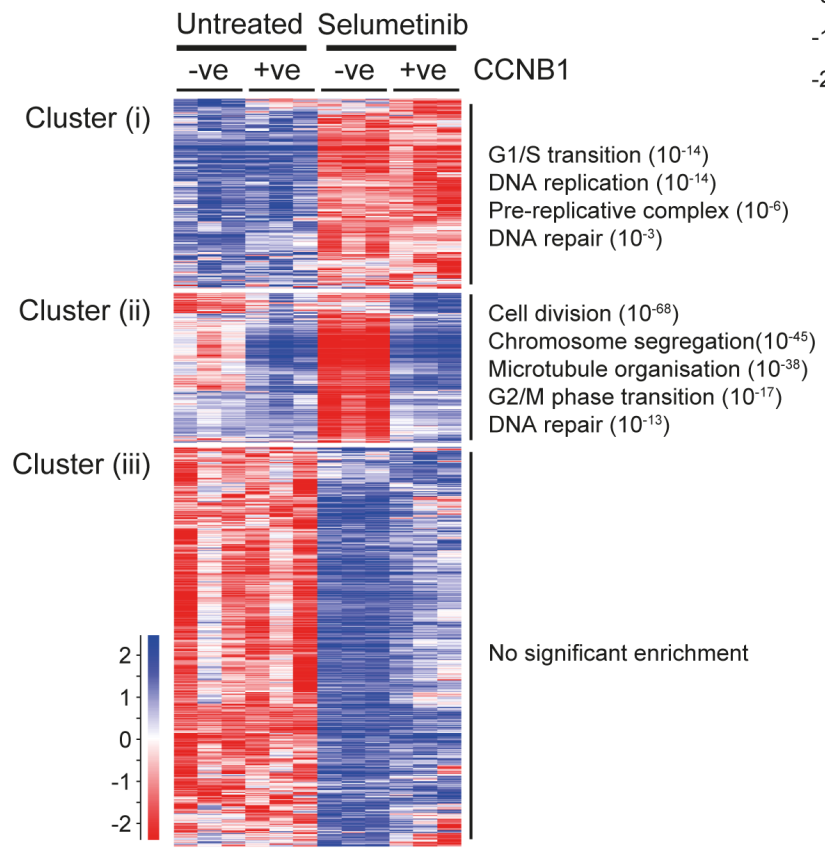

B Time course of gene expression during first 48 hours of selumetinib treatment
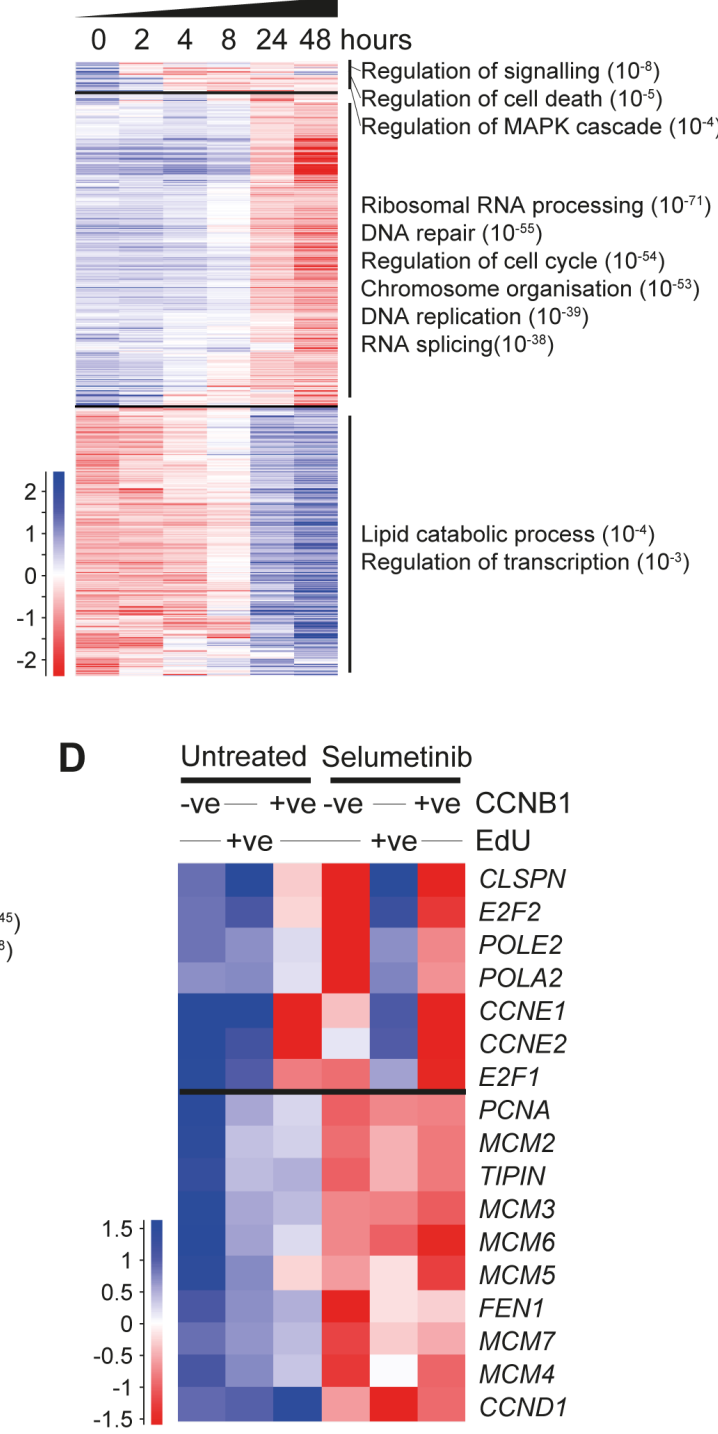
bioRxiv preprint doi: https://doi.org/10.1101/2021.03.23.436572; this version posted March 23, 2021. The copyright holder for this preprint (which was not certified by peer review) is the author/funder, who has granted bioRxiv a license to display the preprint in perpetuity. It is made available under aCC-BY 4.0 International license.

Figure 3: COLO205 cells replicating in selumetinib show defective gene expression

A: Quantification of pERK in EdU negative and positive cells. COLO205 cells were treated with $1 \mu \mathrm{M}$ selumetinib or DMSO only for 24 hours before addition of $10 \mu \mathrm{M}$ EdU for 4 hours in the presence of $1 \mu \mathrm{M}$ selumetinib. Following EdU staining and immunofluorescence with pERK (T202/Y204) antibody, EdU incorporation and pERK levels in cells were determined by high content image analysis. EdU and pERK intensity in untreated (left) and selumetinib treated (right) cells normalised to control cells without addition of EdU or pERK primary antibody are shown. EdU negative and positive cells in individual plots are shown in red and blue rectangular gates respectively.

B. Gene expression across time during selumetinib treatment. COLO205 cells were treated with $1 \mu \mathrm{M}$ selumetinib for up to 48 hours, with cultures harvested at indicated times. The 5782 genes significantly differentially expressed ( $p<0.05$ by DEseq2) between 2 replicates of 0 and 48 hour time points are shown. Genes were categorised into 3 primary behaviours by hierarchical clustering, and representative enriched GO categories $(q<0.05)$ are shown (full GO analysis is presented in Table S1).

C. Differential gene expression between CCNB1 negative and positive COLO205 cells, either untreated or after 24 hours selumetinib treatment. Cells from three biological replicates were fixed with glyoxal, then stained and sorted for CCNB1 followed by mRNAseq library preparation. The 12681 genes shown are significantly ( $p<0.05$ by DEseq 2 ) and substantially (>4-fold) differentially expressed between at least one pair of the four categories shown. Genes were categorised into 3 primary behaviours by hierarchical clustering, and representative enriched GO categories $(q<0.05)$ are shown (full GO analysis is presented in Table S2).

D. Expression of selected replication genes in selumetinib treated and untreated populations sorted for CCNB1 or EdU, representative of the dataset shown in Fig. S3G cluster (i). All genes in this cluster are expressed at a lower level under selumetinib treatment in CCNB1 negative and CCNB1 positive fractions. However the upper cluster of genes is transiently expressed in the $\mathrm{S}$ phase population marked by EdU whereas genes in the lower category are not. CCNB1 positive and negative data are an average of 3 datasets. 
bioRxiv preprint doi: $h$ ttps://doi.org/10.1101/2021.03 23.436572; this version posted March 23, 2021. The copyright holder for this preprint (which was not certified by peer review) is the author/funder, who has granted bioRxiv a license to display the preprint in perpetuity. It is made available under aCC-BY 4.0 International license.

\section{Acquisition of MEKi resistance during DNA replication in drug}

Channathodiyil et al.

A MCM2 and MCM7 in EdU -ve and +ve cells during selumetinib treatment

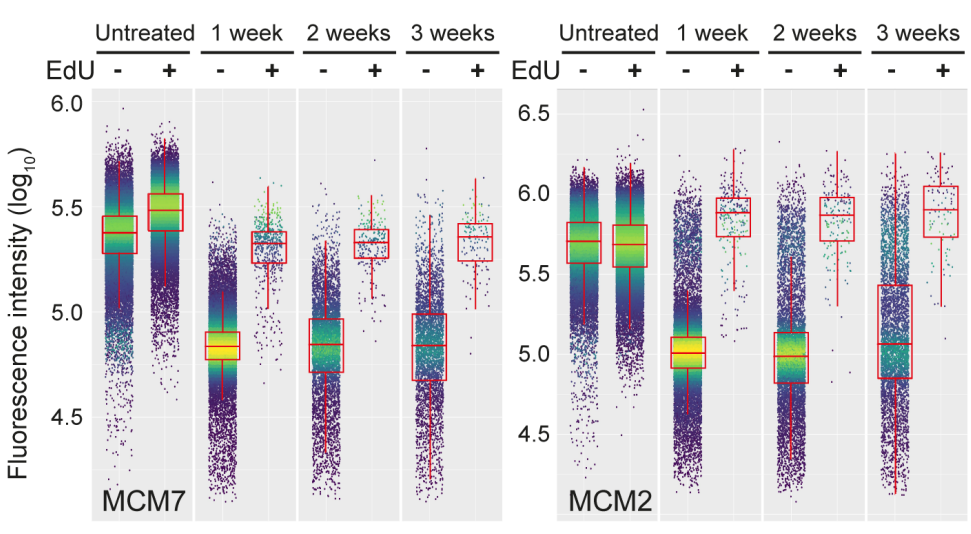

Effect of selumetinib and palbociclib on $\mathrm{pRb}$

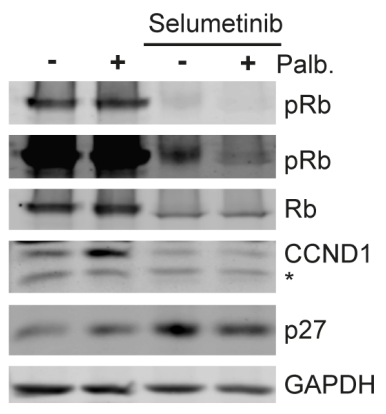

C
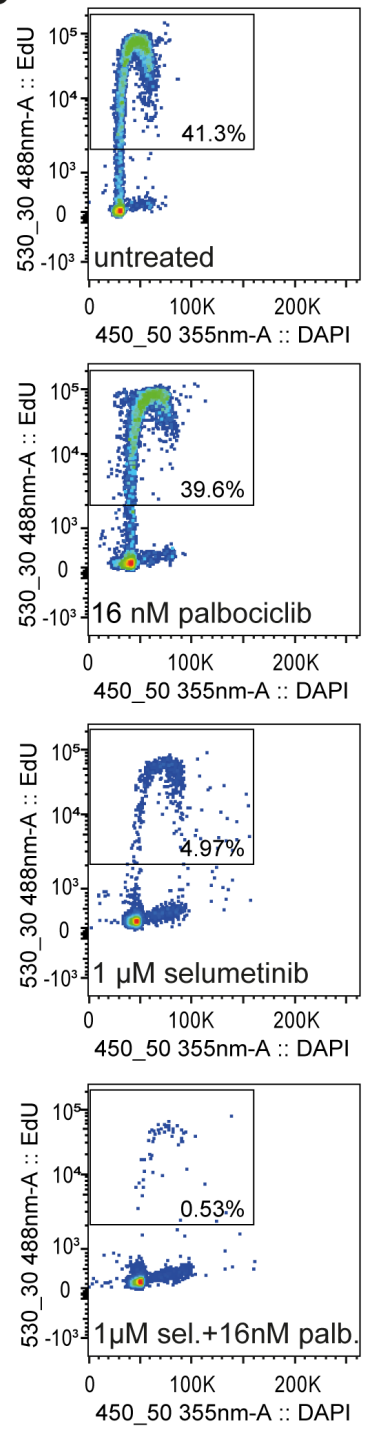

D

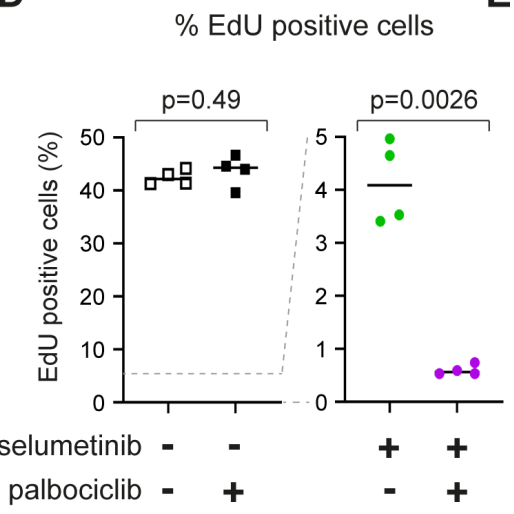

E
Time to resistant clone formation
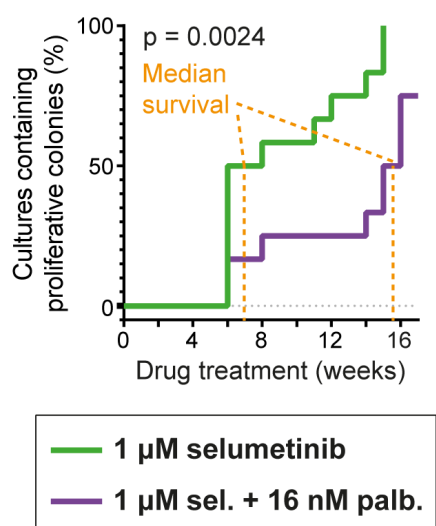

F

Time to resistant clone formation in clonal COLO205 derivatives
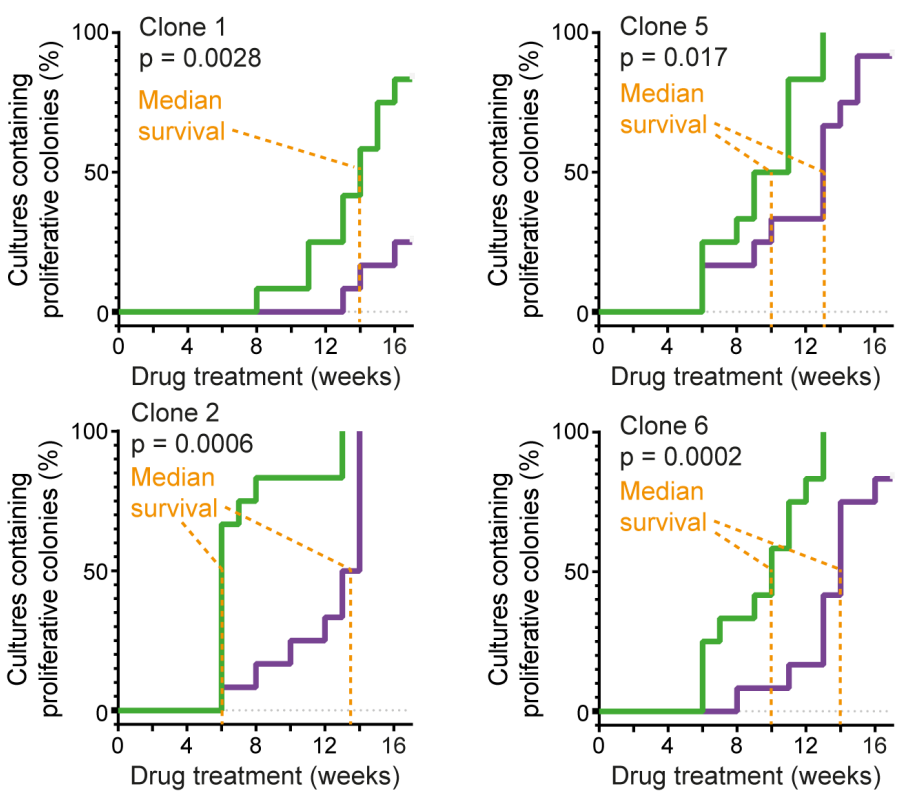
bioRxiv preprint doi: https://doi.org/10.1101/2021.03.23.436572; this version posted March 23, 2021. The copyright holder for this preprint (which was not certified by peer review) is the author/funder, who has granted bioRxiv a license to display the preprint in perpetuity. It is made available under aCC-BY 4.0 International license.

\section{Figure 4: Suppressing DNA replication in selumetinib slows acquisition of resistance}

A. Quantification of MCM2 and MCM7 in EdU negative and positive COLO205 cells treated with $1 \mu \mathrm{M}$ selumetinib or DMSO only (untreated) for 1, 2 and 3 weeks before addition of 10 $\mu \mathrm{M}$ EdU for 4 hours. EdU incorporation and MCM2 and MCM7 levels were determined relative to unstained control cells by high content imaging analysis. Red boxes indicate median signal intensity and inter-quartile range (IQR), whiskers indicate quartile range 1 1.5x IQR and quartile range $3+1.5 x$ IQR.

B. Western blot analysis of COLO205 cells treated with $1 \mu \mathrm{M}$ selumetinib in the presence $(+)$ or absence (-) of $16 \mathrm{nM}$ palbociclib for 24 hours and with the indicated antibodies. Cells treated with DMSO only or $16 \mathrm{nM}$ palbociclib were included as controls. The pRB panels are shown at two different intensities to make the reduction of pRB levels in the combined selumetinib and palbociclib condition visible. Other panels show total Rb, CCND1, p27 (which is also part of the active CCND1-CDK4/6 complex), and GAPDH as a loading control. * indicates non-specific band

C. Quantification of EdU positive cells by flow cytometry in COLO205 cells treated with palbociclib and/or selumetinib at the indicated concentrations for 24 hours before addition of $10 \mu \mathrm{M}$ EdU for 4 hours. Control cells were treated with DMSO only. Individual plots show EdU incorporation and DAPI staining of DNA for each sample as indicated, with rectangles to represent gates used to separate EdU positive and negative cells. Percent EdU positive cells are shown within the gates for each sample.

D. Quantification of EdU positive cells in C. $\mathrm{n}=4$ (2 biological replicates each of parental COLO205 cells and single cell-derived clone 2), p values calculated by $t$ test with Welch's correction.

E. Effect of combined treatment with selumetinib and palbociclib on time taken for the emergence of resistant clones in parental COLO205 cell line. Cells were seeded in 6-well plates and allowed to settle for 24 hours, after which they were treated with $1 \mu \mathrm{M}$ selumetinib in the absence or presence of $16 \mathrm{nM}$ palbociclib. Media and drug were changed weekly, and the time taken for the appearance of first colony ( $\geq 50$ cells) of proliferating cells in each well was recorded (in weeks). 12 independent replicates were performed under each condition, $p$ values were calculated using the Mantel-Cox log-rank test on the principle that emergence of resistance can be represented as survival time of non-resistant cultures.

F. Effect of combined treatment with $1 \mu \mathrm{M}$ selumetinib and $16 \mathrm{~nm}$ palbociclib in single cell derivatives of COLO205 cells determined as in E. Data for 4 different single cell derivatives of COLO205 are shown. 
bioRxiv preprint doi: https://doi.org/10.1101/2021.03.23.436572; this version posted March 23, 2021. The copyright holder for this preprint (which was not certified by peer review) is the author/funder, who has granted bioRxiv a license to display the preprint in perpetuity. It is made available under aCC-BY 4.0 International license.

\section{Acquisition of MEKi resistance during DNA replication in drug Channathodiyil et al.}

A

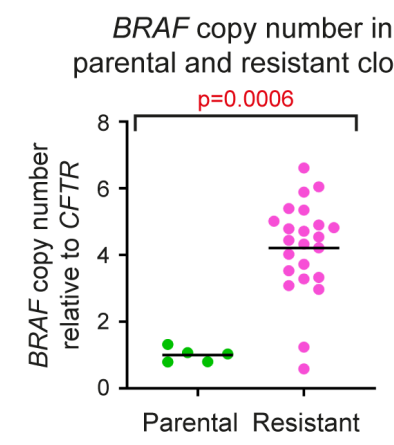

B

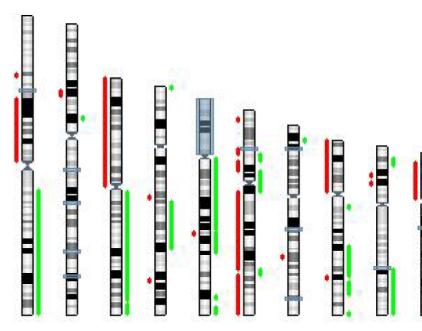

C

$7 q 32$ copy number in parental and resistant clones

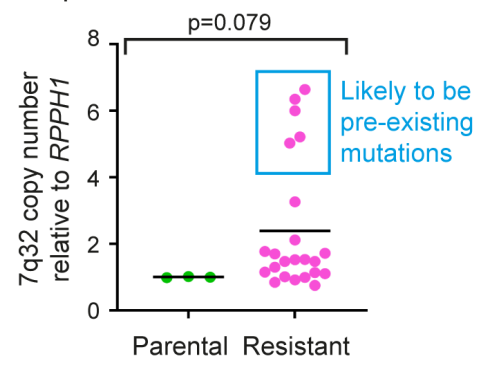

Parental
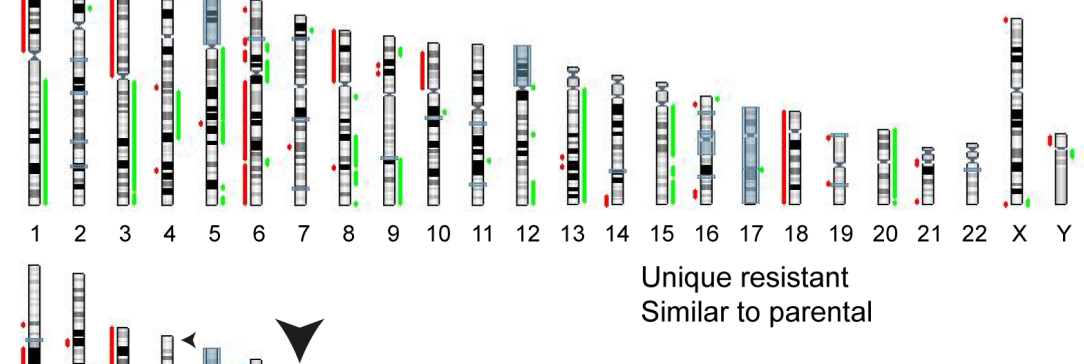

Unique resistant

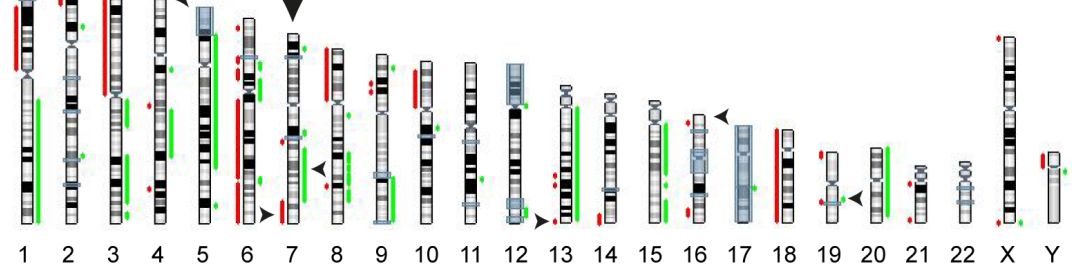

$\begin{array}{llllllllllllllllllllllll}1 & 2 & 3 & 4 & 5 & 6 & 7 & 8 & 9 & 10 & 11 & 12 & 13 & 14 & 15 & 16 & 17 & 18 & 19 & 20 & 21 & 22 & X & Y\end{array}$
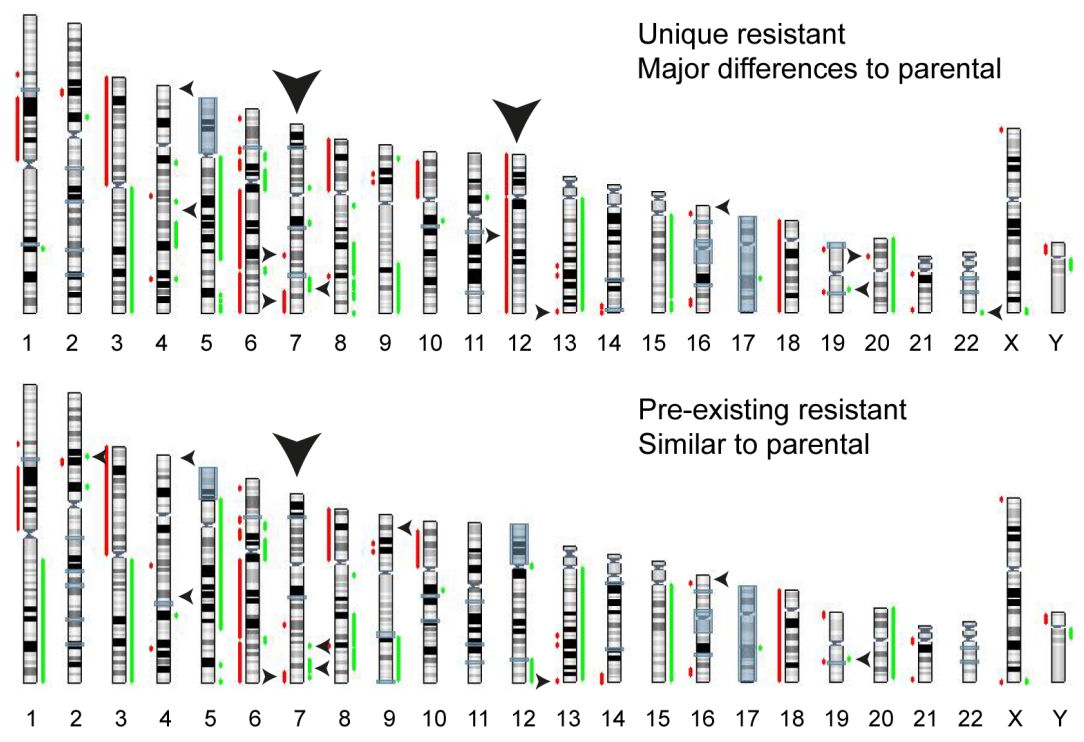
bioRxiv preprint doi: https://doi.org/10.1101/2021.03.23.436572; this version posted March 23, 2021. The copyright holder for this preprint (which was not certified by peer review) is the author/funder, who has granted bioRxiv a license to display the preprint in perpetuity. It is made available under aCC-BY 4.0 International license.

Acquisition of MEKi resistance during DNA replication in drug

Channathodiyil et al.

Figure S1: Supplement to contributions of pre-existing and de novo gene amplifications to the emergence of selumetinib resistance in COLO205 cells

A. qPCR copy number analysis of BRAF (7q34) relative to CFTR (7q31.2) in parental and selumetinib-resistant lines derived as in Fig. 1A. 21 of 23 selumetinib resistant cell lines show $>3$ fold amplification of BRAF relative CFTR. Each assay was performed in triplicate. $\mathrm{p}$ value was calculated by Mann-Whitney test, $n=5$ parental and 23 resistant.

B. Human chromosome ideograms showing CNVs across all chromosomes in parental COLO205 cells and 3 independently derived selumetinib resistant cell lines, profiled as in Figure 1C. CNVs were called by BlueFuse, gains (right of chromosome) and losses (left of chromosomes) are represented in green and red respectively, loss of heterozygosity events are represented by grey boxes. Individual differences between resistant and parental cell lines were examined in primary data and excluded if copy number changes were small $(<0.1)$, and therefore likely to be artefactual, could be explained by mis-calling of end-points of adjacent events. Differences between the lines that were not excluded are noted by small arrows, chromosomes showing differences across substantial regions are denoted by large arrows

C. qPCR copy number analysis of RBM28 (located at 7q32) relative to RPPH1 in parental and selumetinib-resistant lines derived as in Figure 1A. Data for 3 replicates of parental COLO205 cells and 23 independently-derived selumetinib resistant cells lines are shown; 5 of 23 selumetinib resistant cell lines show amplification of BRAF relative RPPH1. Each assay was performed in triplicate. $p$ value was calculated by Mann-Whitney test. 
bioRxiv preprint doi: $h$ ttps://doi.org/10.1101/2021.03 23.436572; this version posted March 23, 2021. The copyright holder for this preprint (which was not certified by peer review) is the author/funder, who has granted bioRxiv a license to display the preprint in perpetuity. It is made available under aCC-BY 4.0 International license.

A
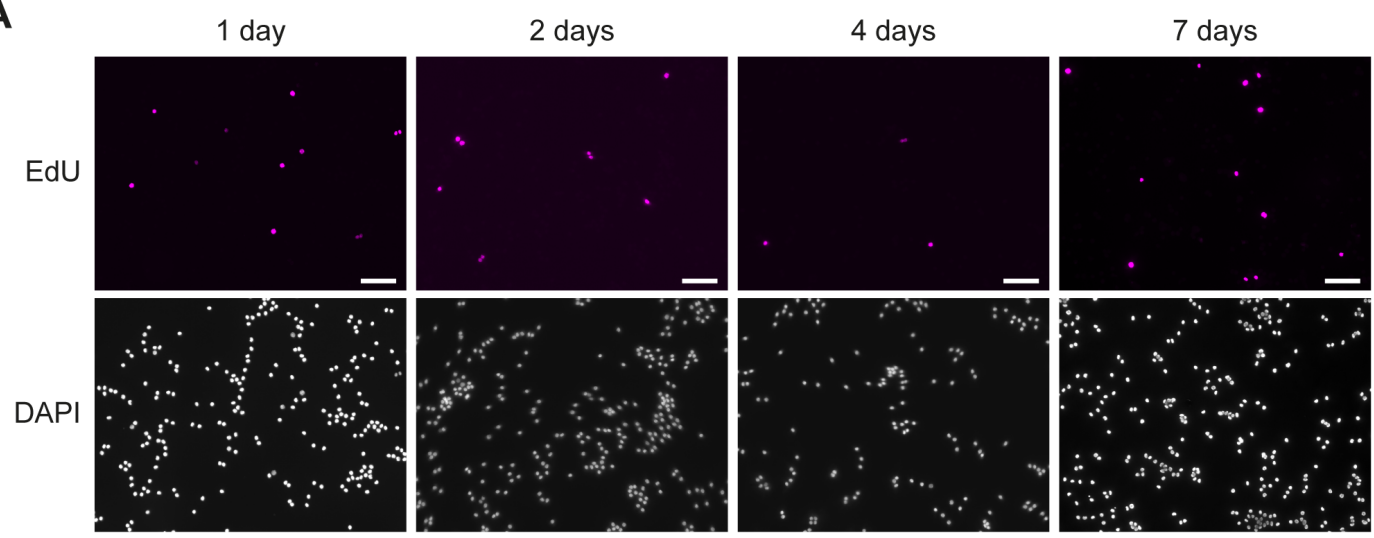

B
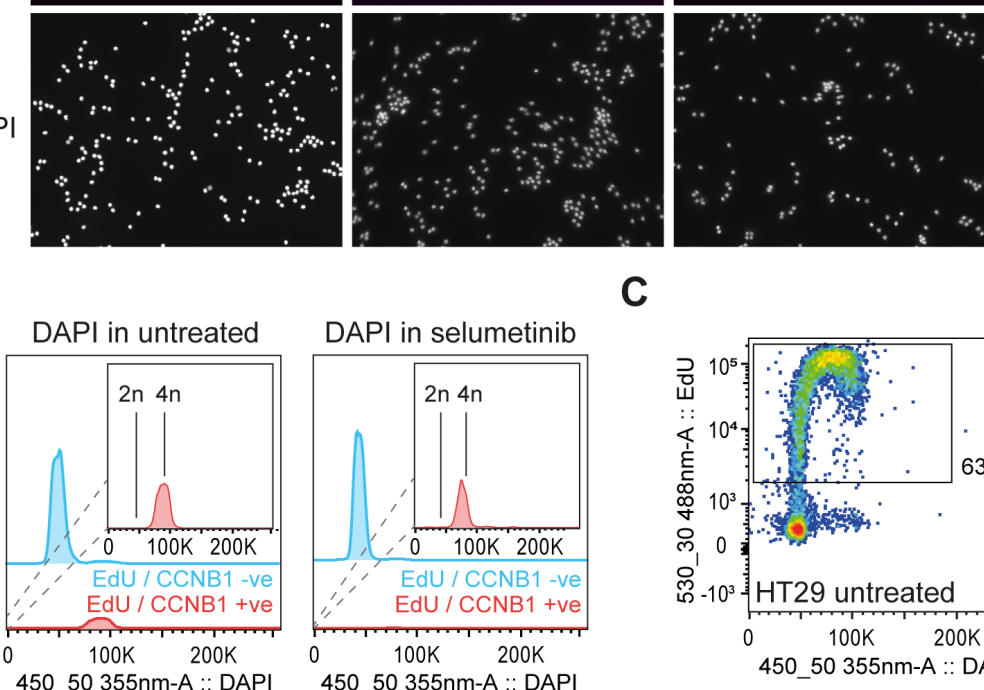

DAPI in selumetinib
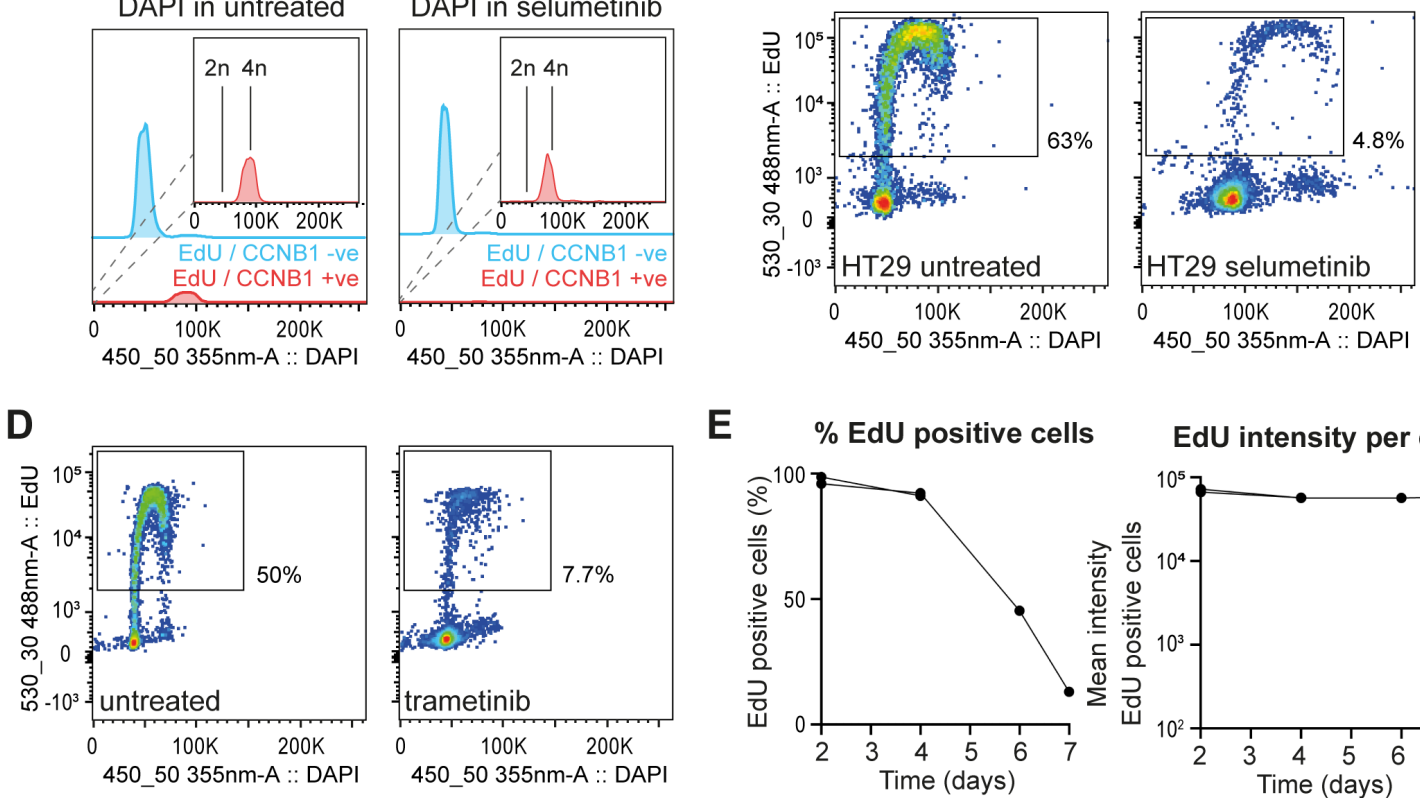

\section{E}

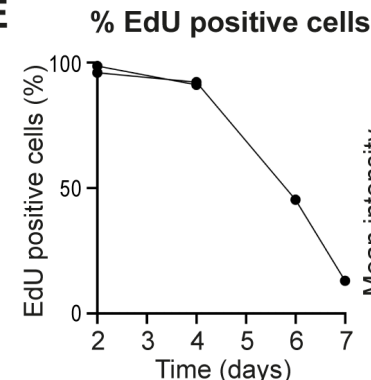

EdU intensity per cell

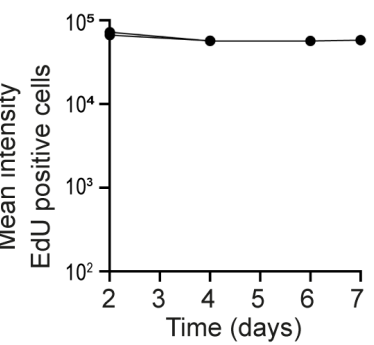


bioRxiv preprint doi: $\mathrm{https}$ ://doi.org/10.1101/2021.03.23.436572; this version posted March 23, 2021. The copyright holder for this preprint (which was not certified by peer review) is the author/funder, who has granted bioRxiv a license to display the preprint in perpetuity. It is made available under aCC-BY 4.0 International license.

Acquisition of MEKi resistance during DNA replication in drug

Channathodiyil et al.

Figure S2: Supplement to replicating cells persist in long-term Selumetinib-treated cell cultures

A. EdU positive cells during prolonged selumetinib treatment. COLO205 cells were treated with $1 \mu \mathrm{M}$ selumetinib for the indicated duration before addition of $10 \mu \mathrm{M}$ EdU for 24 hours in the presence of selumetinib. EdU positive cells (pink) co-stained with DAPI (grey) from selumetinib treated cells are shown, scale bars represent $100 \mu \mathrm{m}$.

B. Fluorescence histograms of DAPI intensities for EdU / CCNB1 double negatives and double positives in untreated (left) and $1 \mu \mathrm{M}$ selumetinib treated (right) COLO205 cells. Cells were treated with $1 \mu \mathrm{M}$ selumetinib or DMSO only for 24 hours before addition of $10 \mu \mathrm{M}$ EdU for 4 hours. EdU incorporation, CCNB1 and DAPI incorporation were determined by flow cytometry. Inset plots show DAPI intensities of EdU-CCNB1 double positives re-scaled to make rare EdU / CCNB1 double positive signals visible.

C. Quantification of EdU positive cells by flow cytometry in HT29 cells grown in the absence and presence of selumetinib. HT29 cells were treated with $1 \mu \mathrm{M}$ selumetinib or DMSO only (untreated) for 24 hours before addition of $10 \mu \mathrm{M}$ EdU for 4 hours. EdU incorporation was detected by flow cytometry. Individual plots show EdU incorporation and DAPI staining of DNA for untreated (left) and selumetinib treated cells (right), with rectangles to indicate gates used to quantify EdU positive and negative cells.

D. Quantification of EdU positive cells by flow cytometry in COLO205 cells grown in the absence and presence of trametinib. Single-cell clone derivative (clone 1) of COL0205 cells were treated with $3 \mathrm{nM}$ trametinib or DMSO only (untreated) for 24 hours before addition of $10 \mu \mathrm{M}$ EdU for 24 hours in the presence of $3 \mathrm{nM}$ trametinib. EdU incorporation was detected by flow cytometry. Individual plots show EdU incorporation and DAPI staining of DNA for untreated (left) and selumetinib treated cells (right), with rectangles to indicate gates used to quantify EdU positive and negative cells.

E. Quantification of EdU positive cells following a 24-hour EdU pulse during growth in the absence of selumetinib. COLO205 cells were treated with $2 \mu \mathrm{M}$ EdU then washed with media and grown in culture for a period of 7 days. EdU incorporation was determined by flow cytometry on the indicated days, showing quantitation of EdU positive cells (left) and EdU intensity per cell (right), $n=3$. See Fig. 2E for more details. 
bioRxiv preprint doi: $h t t p s: / / d o i . o r g / 10.1101 / 2021.03 .23 .436572$; this version posted March 23, 2021. The copyright holder for this preprint (which was not certified by peer review) is the author/funder, who has granted bioRxiv a license to display the preprint in perpetuity. It is made available under aCC-BY 4.0 International license.

\section{Acquisition of MEKi resistance during DNA replication in drug}

Channathodiyil et al.

A

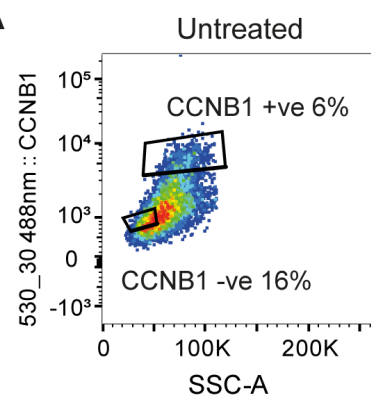

B

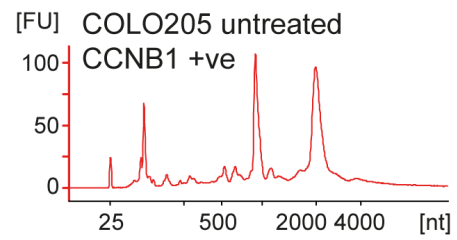

[FU] COLO205 untreated

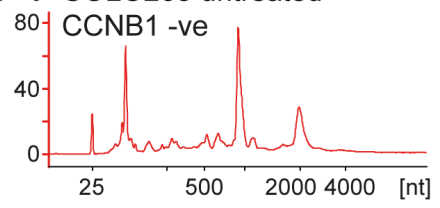

Selumetinib

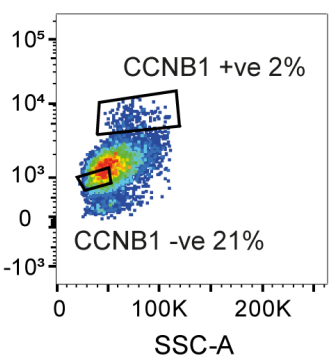

$E$

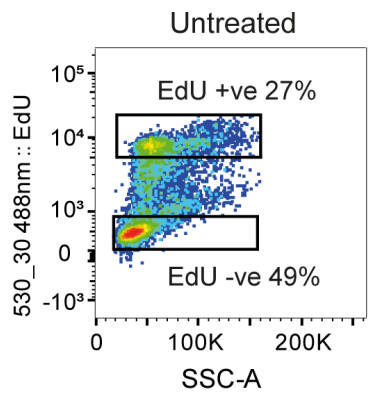

Selumetinib

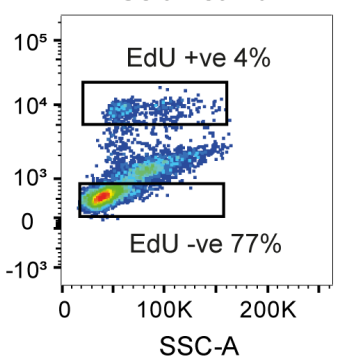

F $[\mathrm{FU}]$ COLO205 selumetinib
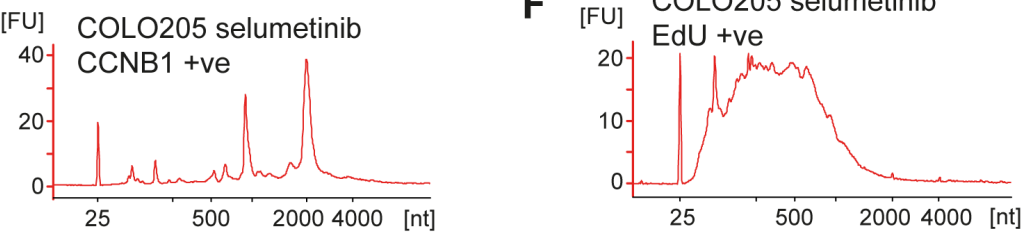

[FU] COLO205 selumetinib

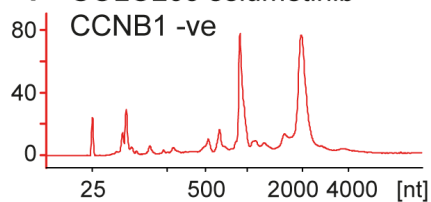

COLO205 untreated

[FU] $\mathrm{EdU}+\mathrm{ve}$

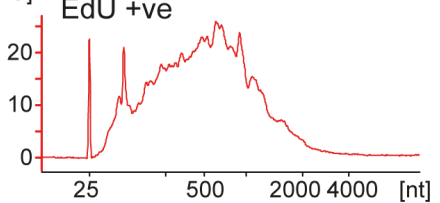

C

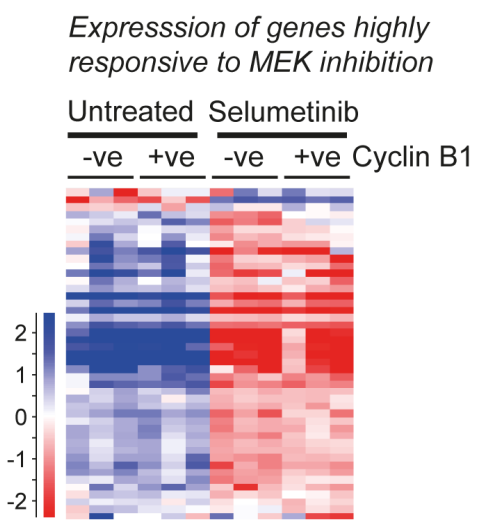

D Expresssion of MEK signature genes

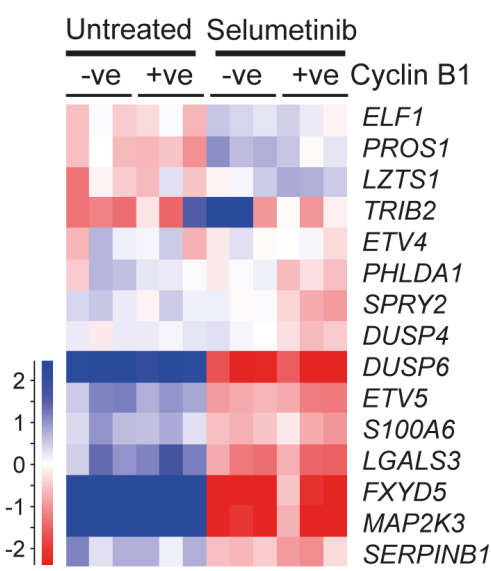

G

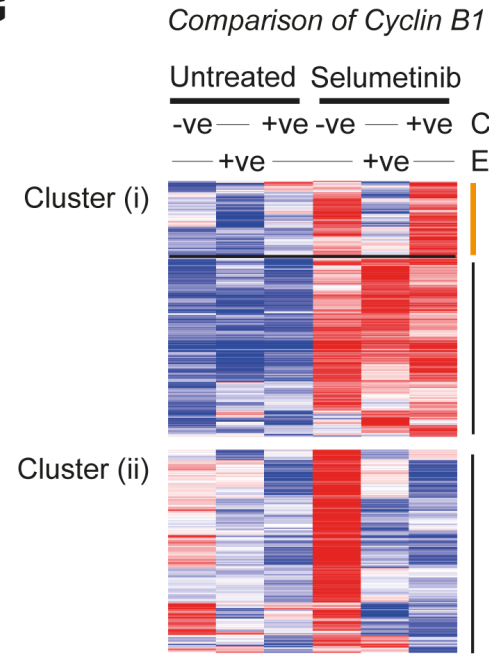

Cluster (iii)

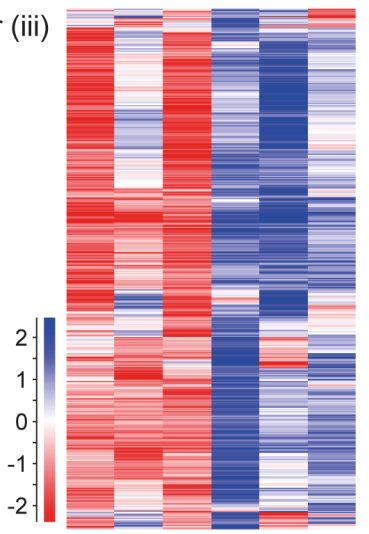

Cyclin B1

EdU

G1/S transition $\left(10^{-3}\right)$ DNA replication $\left(10^{-2}\right)$

G1/S transition $\left(10^{-8}\right)$

DNA replication $\left(10^{-8}\right)$

DNA replication initiation $\left(10^{-8}\right)$

Pre-replicative complex $\left(10^{-5}\right)$

Regulation of ERK1/2 cascade $\left(10^{-2}\right)$

Cell division $\left(10^{-63}\right)$

Chromosome segregation $\left(10^{-45}\right)$

Microtubule organisation $\left(10^{-40}\right)$

G2/M phase transition $\left(10^{-17}\right)$

DNA repair $\left(10^{-12}\right)$ 
bioRxiv preprint doi: https://doi.org/10.1101/2021.03.23.436572; this version posted March 23, 2021. The copyright holder for this preprint (which was not certified by peer review) is the author/funder, who has granted bioRxiv a license to display the preprint in perpetuity. It is made available under aCC-BY 4.0 International license.

Acquisition of MEKi resistance during DNA replication in drug

Channathodiyil et al.

\section{Figure S3: Supplement to gene expression analysis of replicating cells}

A. Flow cytometry density plot for COLO205 cells labelled with anti-CCNB1 primary antibody and donkey Alexa Fluor-488 conjugated secondary antibody and sorted using a BD FACSAria III sorter. Fluorescence thresholds for isolation of CCNB1 positive and negative cell fractions are shown. Gates were set based on a negative control staining without primary antibody, and the CCNB1 positive and negative sorting gates were set apart from each other to maximise sort purity.

B. Bioanalyzer profiles of total RNA isolated from CCNB1 positive and negative cells in untreated and $1 \mu \mathrm{M}$ selumetinib treated cells sorted by flow cytometry using a BD FACSAria III sorter. 0.1-5 ng of total RNA was separated on total RNA pico chips on Agilent 2100 Bioanalyzer

C: Hierarchical clustering of gene set identified by Pratilas et al. (47) as significantly altered on MEK inhibition, showing relative expression in CCNB1 positive and negative fractions in the absence and presence of $1 \mu \mathrm{M}$ selumetinib.

D. Hierarchical clustering of signature genes for MEK activity identified by Dry et al. (49) in CCNB1 positive and negative fractions in the absence and presence of $1 \mu \mathrm{M}$ selumetinib.

E. Flow cytometry density plot for COLO205 cells stained for EdU and sorted using a BD FACSAria III sorter. Fluorescence thresholds for isolation of EdU positive and negative cell fractions are shown. Gates were set using the unstained negative control and the EdU positive and negative sorting gates were set apart from each other to maximise sort purity.

F. Bioanalyzer profiles of total RNA isolated from EdU positive cells in untreated and $1 \mu \mathrm{M}$ selumetinib treated cells sorted by flow cytometry using a BD FACSAria III sorter. 0.1-5 ng of total RNA was separated on total RNA pico chips on Agilent 2100 Bioanalyzer

G. Hierarchical clustering analysis of the three clusters of genes significantly and substantially differentially expressed amongst CCNB1 positive and negative selumetinib treated cells and controls, as defined in Fig. 3C. CCNB1 data represents an average of 3 biological replicates, compared with EdU positive cells isolated from selumetinib treated and control cells in $\mathbf{E}$. Gene expression data from EdU positive cells is similar to CCNB1 positive cells, except for the upper set of genes in cluster (i), highlighted in orange, that show transient upregulation in replicating cells. The full list of enriched GO categories $(q<0.05)$ is presented in Table S3. 
bioRxiv preprint doi: $h t t p s: / / d o i . o r g / 10.1101 / 2021.03 .23 .436572$; this version posted March 23, 2021. The copyright holder for this preprint (which was not certified by peer review) is the author/funder, who has granted bioRxiv a license to display the preprint in perpetuity. It is made available under aCC-BY 4.0 International license.

\section{Acquisition of MEKi resistance during DNA replication in drug Channathodiyil et al.}

A

MCM2 and MCM7 in EdU -ve and +ve cells during selumetinib treatment

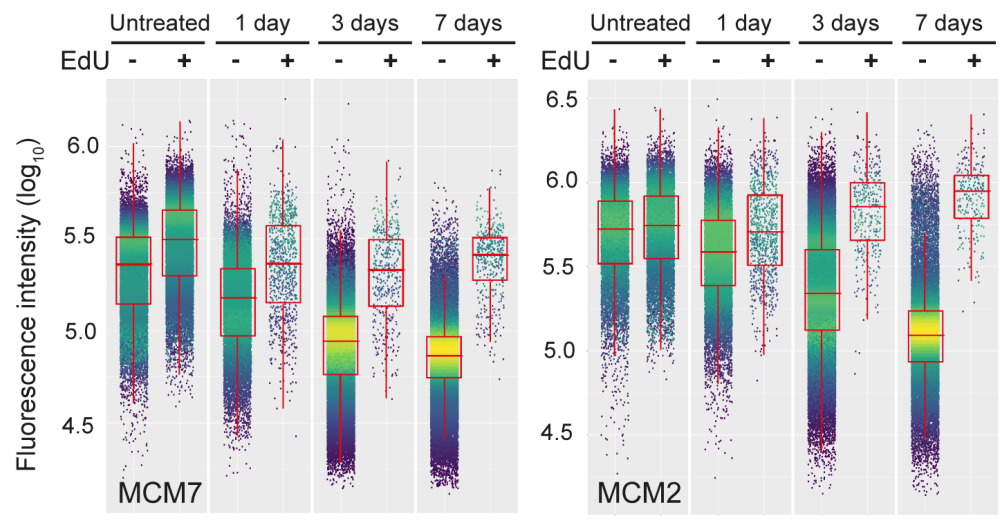

B CCND1 expression compared to GAPDH in untreated and selumetinib treated cells

C

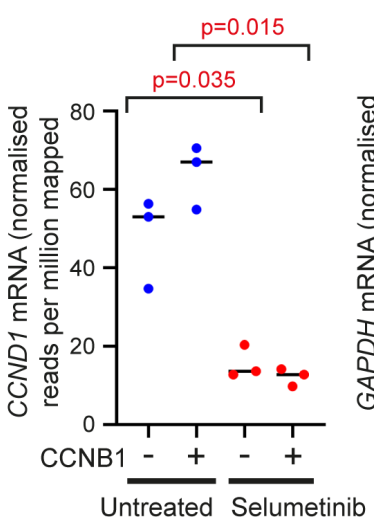

D

Colony formation of COLO205
cells in $16 \mathrm{nM}$ palbociclib

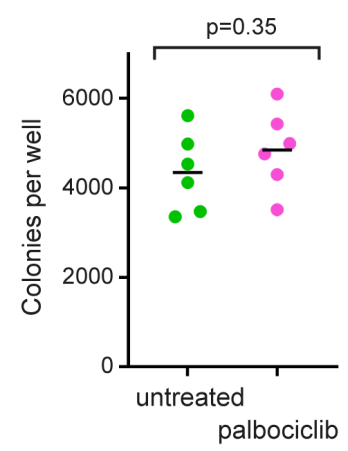

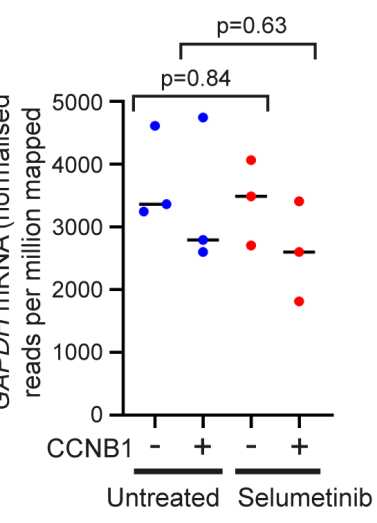

E

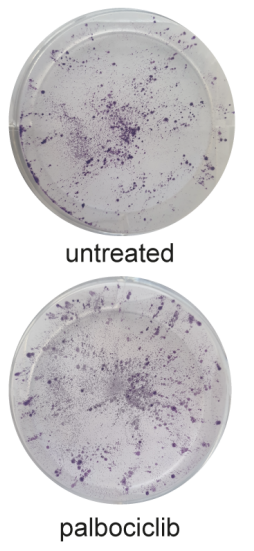

Growth of COLO205 cells in $16 \mathrm{nM}$ palbociclib

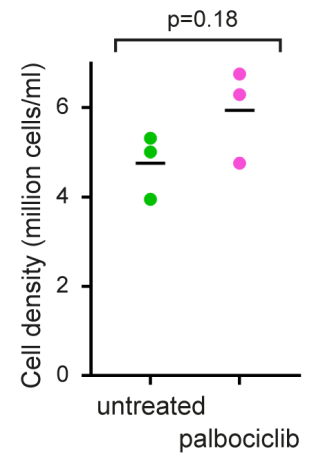

$B R A F$ copy number in resistant cells emerging in selumetinib or selumetinib + palbociclib

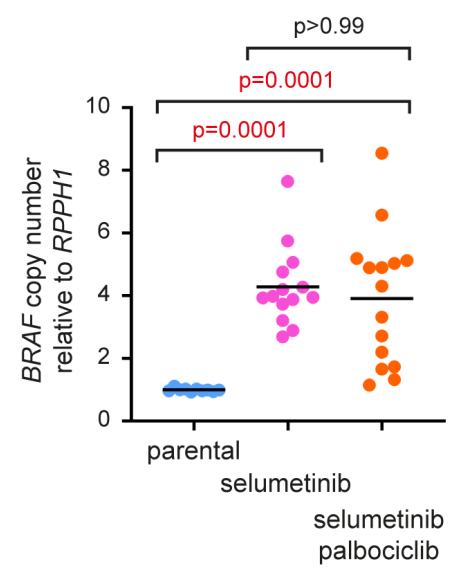

Figure S4: Supplement to suppressing DNA replication in selumetinib slows acquisition of resistance

A. Quantification of MCM2 and MCM7 in EdU negative and positive COLO205 cells treated with $1 \mu \mathrm{M}$ selumetinib or DMSO only (untreated) for 1,3 and 7 days before addition of $10 \mu \mathrm{M}$ EdU for 4 hours. EdU incorporation and $\mathrm{MCM} 2$ and $\mathrm{MCM} 7$ levels were determined relative to unstained control cells by high content imaging analysis. Red boxes indicate median signal 
bioRxiv preprint doi: $\mathrm{https}$ ://doi.org/10.1101/2021.03.23.436572; this version posted March 23, 2021. The copyright holder for this preprint (which was not certified by peer review) is the author/funder, who has granted bioRxiv a license to display the preprint in perpetuity. It is made available under aCC-BY 4.0 International license.

Acquisition of MEKi resistance during DNA replication in drug

Channathodiyil et al.

intensity and inter-quartile range (IQR), whiskers indicate quartile range $1-1.5 x$ IQR and quartile range $3+1.5 x$ IQR .

B. Expression of CCND1 (Cyclin D1) in untreated and selumetinib treated cells compared to $G A P D H$ as an example housekeeping gene. Normalised read counts (reads per million mapped) from mRNA-seq of CCNB1 negative and positive cells show that CCND1 expression is substantially repressed by selumetinib treatment, and is not upregulated in cells that have entered the cell cycle. $n=3$ biological replicates, $p$-values calculated by one-way ANOVA with a Brown-Forsythe and Welch correction.

C. Effect of single agent administration of palbociclib on cell growth in COLO205 cells. Cells were treated with $16 \mathrm{nM}$ palbociclib or DMSO only and incubated for 7 days. Cells were harvested by trypsinisation and cell pellet resuspended in $1 \mathrm{~mL}$ culture media. Cells were counted using a Countess automated cell counter at the indicated times. $p$ value calculated by $t$ test, $n=3$ biological replicates.

D. Effect of single agent administration of palbociclib on colony formation in COLO205 cells. Cells were treated with $16 \mathrm{nM}$ palbociclib or DMSO only and incubated for 24 hours. Following treatment, cells were harvested by trypsinisation and 100 cells seeded per well in 6-well plates in the absence or presence of $16 \mathrm{nM}$ palbociclib and incubated for 21 days. Colonies were fixed and stained in $0.4 \%$ crystal violet in $50 \%$ methanol (representative images shown). $p$ value calculated by $t$ test, $n=6$ biological replicates per condition.

E: qPCR copy number analysis of BRAF relative to RPPH1 in parental and selumetinib-resistant cell lines derived in selumetinib alone or selumetinib + palbociclib. COLO205 cells were treated with $1 \mu \mathrm{M}$ selumetinib in the presence and absence of $16 \mathrm{nM}$ palbociclib, and media and drug changed weekly until colonies of proliferating cells were observed. BRAF copy number relative to RPPH1 in independent resistant clones was determined by qPCR analysis; DNA from log phase culture of parental COLO205 cells was used as control. Each sample was assayed in triplicate. $p$ values were calculated by Kruskal-Wallis test ( $n=10$ parental, 14 selumetinib, 15 selumetinib + palbociclib). 